Cochrane Database of Systematic Reviews

\title{
Glutamine supplementation to prevent morbidity and mortality in preterm infants (Review)
}

Moe-Byrne T, Brown JVE, McGuire W

Moe-Byrne T, Brown JVE, McGuire W.

Glutamine supplementation to prevent morbidity and mortality in preterm infants.

Cochrane Database of Systematic Reviews 2016, Issue 4. Art. No.: CD001457.

DOI: 10.1002/14651858.CD001457.pub6.

www.cochranelibrary.com 
TABLE OF CONTENTS

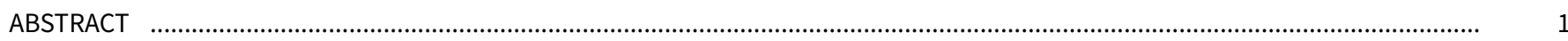

PLAIN LANGUAGE SUMMARY

SUMMARY OF FINDINGS

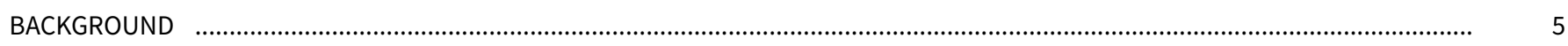

OBJECTIVES

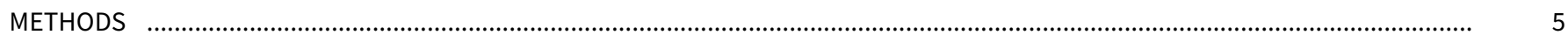

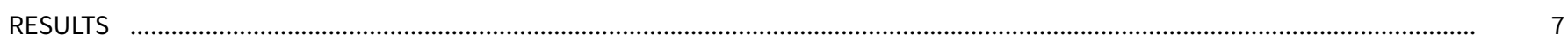

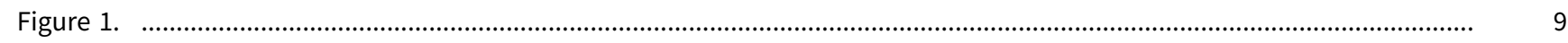

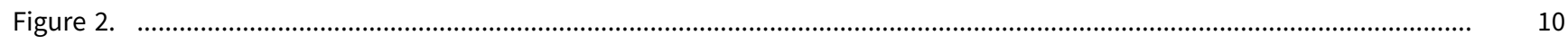

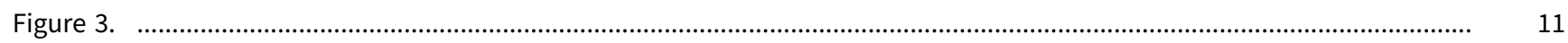

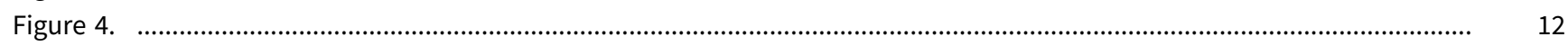

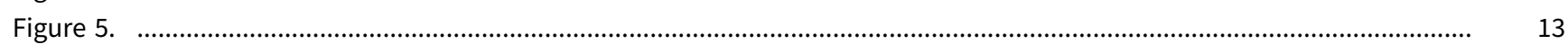

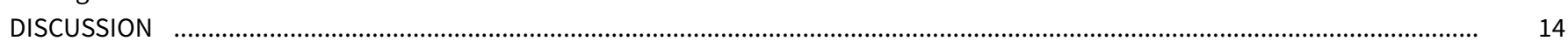

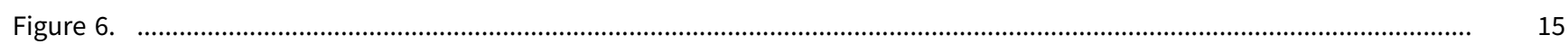

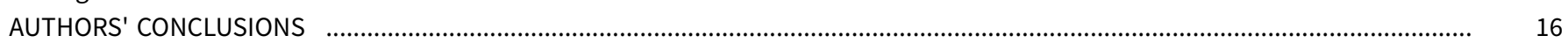

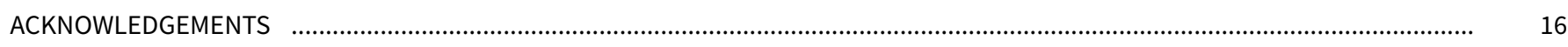

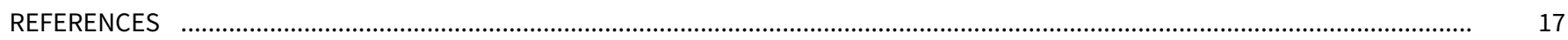

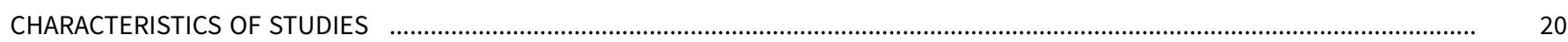

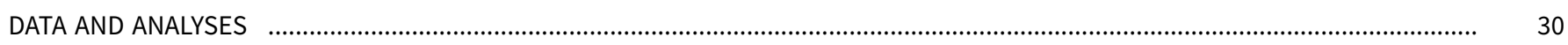

Analysis 1.1. Comparison 1 Glutamine supplementation versus no supplementation, Outcome 1 Death prior to hospital 32 discharge.

Analysis 1.2. Comparison 1 Glutamine supplementation versus no supplementation, Outcome 2 Neurodevelopmental 32 impairment.

Analysis 1.3. Comparison 1 Glutamine supplementation versus no supplementation, Outcome 3 Invasive infection. ..............

Analysis 1.4. Comparison 1 Glutamine supplementation versus no supplementation, Outcome 4 Necrotising enterocolitis. .....

Analysis 1.5. Comparison 1 Glutamine supplementation versus no supplementation, Outcome 5 Rate of weight gain (g/day). ..

Analysis 1.6. Comparison 1 Glutamine supplementation versus no supplementation, Outcome 6 Time to full enteral nutrition (days).

Analysis 1.7. Comparison 1 Glutamine supplementation versus no supplementation, Outcome 7 Duration of hospital stay (days).

Analysis 2.1. Comparison 2 Trials in low- and middle-income countries, Outcome 1 Death prior to hospital discharge. ............

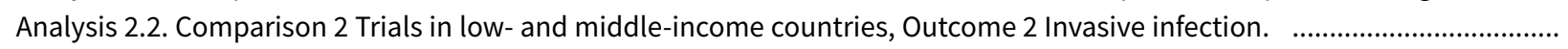

Analysis 2.3. Comparison 2 Trials in low- and middle-income countries, Outcome 3 Necrotising enterocolitis. .......................

Analysis 2.4. Comparison 2 Trials in low- and middle-income countries, Outcome 4 Rate of weight gain (g/day). ...................

Analysis 2.5. Comparison 2 Trials in low- and middle-income countries, Outcome 5 Time to full enteral nutrition (days). ........

Analysis 2.6. Comparison 2 Trials in low- and middle-income countries, Outcome 6 Duration of hospital stay (days). .............. APPENDICES

FEEDBACK

WHAT'S NEW

HISTORY

CONTRIBUTIONS OF AUTHORS

DECLARATIONS OF INTEREST

SOURCES OF SUPPORT

DIFFERENCES BETWEEN PROTOCOL AND REVIEW

INDEX TERMS 
[Intervention Review]

\section{Glutamine supplementation to prevent morbidity and mortality in preterm infants}

Thirimon Moe-Byrne ${ }^{1}$, Jennifer VE Brown² ${ }^{2}$ William McGuire ${ }^{3}$

${ }^{1}$ Centre for Reviews and Dissemination, University of York, York, UK. ${ }^{2}$ Centre for Reviews and Dissemination, University of York, York, UK. ${ }^{3}$ Hull York Medical School \& Centre for Reviews and Dissemination, University of York, York, UK

Contact: William McGuire, Hull York Medical School \& Centre for Reviews and Dissemination, University of York, York, Y010 5DD, UK. William.McGuire@hyms.ac.uk.

Editorial group: Cochrane Neonatal Group.

Publication status and date: New search for studies and content updated (no change to conclusions), published in Issue 4, 2016.

Citation: Moe-Byrne T, Brown JVE, McGuire W. Glutamine supplementation to prevent morbidity and mortality in preterm infants. Cochrane Database of Systematic Reviews 2016, Issue 4. Art. No.: CD001457. DOI: 10.1002/14651858.CD001457.pub6.

Copyright (c) 2016 The Cochrane Collaboration. Published by John Wiley \& Sons, Ltd.

\section{A B S T R A C T}

\section{Background}

Glutamine is a conditionally essential amino acid. Endogenous biosynthesis may be insufficient for tissue needs in states of metabolic stress. Evidence exists that glutamine supplementation improves clinical outcomes in critically ill adults. It has been suggested that glutamine supplementation may also benefit preterm infants.

\section{Objectives}

To determine the effects of glutamine supplementation on mortality and morbidity in preterm infants.

\section{Search methods}

We used the standard search strategy of the Cochrane Neonatal Review Group. This included searches of the Cochrane Central Register of Controlled Trials (CENTRAL, 2015, Issue 12), MEDLINE, EMBASE and Maternity and Infant Care (to December 2015), conference proceedings and previous reviews.

\section{Selection criteria}

Randomised or quasi-randomised controlled trials that compared glutamine supplementation versus no glutamine supplementation in preterm infants at any time from birth to discharge from hospital.

\section{Data collection and analysis}

We extracted data using the standard methods of the Cochrane Neonatal Review Group, with separate evaluation of trial quality and data extraction by two review authors. We synthesised data using a fixed-effect model and reported typical relative risk, typical risk difference and weighted mean difference.

\section{Main results}

We identified 12 randomised controlled trials in which a total of 2877 preterm infants participated. Six trials assessed enteral glutamine supplementation and six trials assessed parenteral glutamine supplementation. The trials were generally of good methodological quality. Meta-analysis did not find an effect of glutamine supplementation on mortality (typical relative risk $0.97,95 \%$ confidence interval 0.80 to 1.17; risk difference $0.00,95 \%$ confidence interval -0.03 to 0.02 ) or major neonatal morbidities including the incidence of invasive infection or necrotising enterocolitis. Three trials that assessed neurodevelopmental outcomes in children aged 18 to 24 months and beyond did not find any effects. 


\section{Authors' conclusions}

The available trial data do not provide evidence that glutamine supplementation confers important benefits for preterm infants.

\section{PLAIN LANGUAGE SUMMARY}

\section{Glutamine supplementation to prevent morbidity and mortality in preterm infants}

Review question: In preterm infants, does glutamine supplementation reduce the risk of death or disability?

Background: Glutamine is an important nutrient for growth and development and may be especially important in protecting preterm infants from infections and gut problems that cause death and disability. We sought evidence that giving preterm infants extra glutamine improves important outcomes.

Study characteristics: We found 12 randomised controlled trials (enrolling 2877 infants in total). The trials were generally of good methodological quality.

Key results: These trials did not provide strong or consistent evidence that glutamine supplementation affected the risk of death, serious infection or bowel disease, or longer term development.

Conclusions: Glutamine supplementation is not likely to be beneficial for preterm infants. 


\begin{tabular}{|c|c|c|c|c|c|}
\hline \multirow{8}{*}{ 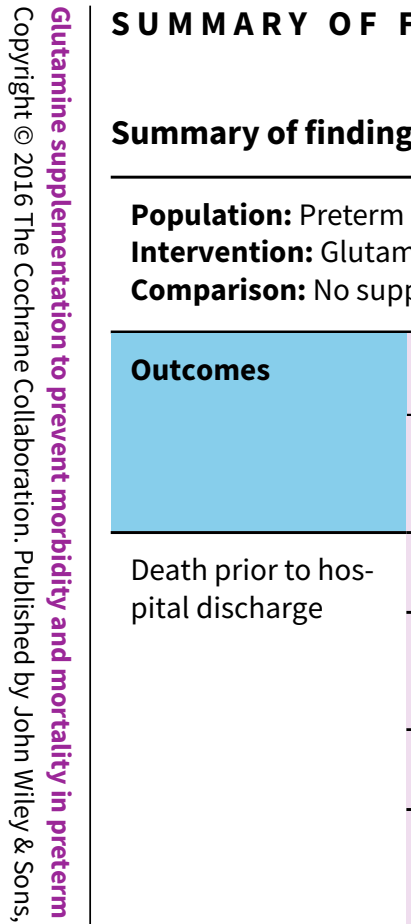 } & $\begin{array}{l}\text { I N D I N G S } \\
\text { s for the main comparison. }\end{array}$ & \multicolumn{3}{|c|}{ Glutamine supplementation to prevent morbidity and mortality in preterm infant } & 5 \\
\hline & $\begin{array}{l}\text { infants } \\
\text { ine supplementation } \\
\text { plementation }\end{array}$ & & & & \\
\hline & \multicolumn{2}{|c|}{ Anticipated absolute effects ${ }^{*}(95 \% \mathrm{Cl})$} & \multirow{2}{*}{$\begin{array}{l}\text { Relative effect } \\
(95 \% \mathrm{Cl})\end{array}$} & \multirow{2}{*}{$\begin{array}{l}\text { № of participants } \\
\text { (studies) }\end{array}$} & \multirow{2}{*}{$\begin{array}{l}\text { Quality of the evi- } \\
\text { dence } \\
\text { (GRADE) }\end{array}$} \\
\hline & $\begin{array}{l}\text { Risk with no supplementa- } \\
\text { tion }\end{array}$ & Risk with Glutamine supplementation & & & \\
\hline & \multicolumn{2}{|l|}{ Study population } & \multirow{4}{*}{$\begin{array}{l}\text { RR } 0.97 \\
(0.80 \text { to } 1.17)\end{array}$} & \multirow{4}{*}{$\begin{array}{l}2877 \\
(12 \text { RCTs })\end{array}$} & \multirow{4}{*}{$\begin{array}{l}\oplus \oplus \oplus \oplus \\
\mathrm{HIGH}\end{array}$} \\
\hline & 123 per 1000 & $\begin{array}{l}119 \text { per } 1000 \\
\text { (98 to } 144)\end{array}$ & & & \\
\hline & \multicolumn{2}{|l|}{ Moderate } & & & \\
\hline & 80 per 1000 & $\begin{array}{l}78 \text { per } 1000 \\
(64 \text { to } 94)\end{array}$ & & & \\
\hline \multirow{4}{*}{$\begin{array}{l}\text { Neurodevelopmen- } \\
\text { tal impairment }\end{array}$} & \multicolumn{2}{|l|}{ Study population } & \multirow{4}{*}{$\begin{array}{l}\text { RR } 1.07 \\
\text { (0.59 to } 1.92)\end{array}$} & \multirow{4}{*}{$\begin{array}{l}72 \\
(1 \mathrm{RCT})\end{array}$} & \multirow{4}{*}{$\begin{array}{l}\oplus \oplus \ominus \odot \\
\text { LOW } 1\end{array}$} \\
\hline & 375 per 1000 & $\begin{array}{l}401 \text { per } 1000 \\
(221 \text { to } 720)\end{array}$ & & & \\
\hline & \multicolumn{2}{|l|}{ Moderate } & & & \\
\hline & 375 per 1000 & $\begin{array}{l}401 \text { per } 1000 \\
\text { (221 to } 720)\end{array}$ & & & \\
\hline \multirow[t]{4}{*}{ Invasive infection } & Study population & & \multirow{4}{*}{$\begin{array}{l}\text { RR } 0.94 \\
\text { (0.86 to } 1.04)\end{array}$} & \multirow{4}{*}{$\begin{array}{l}2815 \\
\text { (11 RCTs) }\end{array}$} & \multirow{4}{*}{$\begin{array}{l}\oplus \oplus \oplus \ominus \\
\text { MODERATE 2,3 }\end{array}$} \\
\hline & 368 per 1000 & $\begin{array}{l}346 \text { per } 1000 \\
\text { (316 to } 383 \text { ) }\end{array}$ & & & \\
\hline & \multicolumn{2}{|l|}{ Moderate } & & & \\
\hline & 364 per 1000 & $\begin{array}{l}342 \text { per } 1000 \\
(313 \text { to } 379)\end{array}$ & & & \\
\hline
\end{tabular}




\begin{tabular}{|c|c|c|c|c|c|}
\hline \multirow{4}{*}{$\begin{array}{l}\mid \begin{array}{l}\text { Necrotising entero- } \\
\text { colitis }\end{array}\end{array}$} & \multicolumn{2}{|c|}{ Study population } & \multirow{4}{*}{$\begin{array}{l}\mathrm{RR} 0.83 \\
(0.66 \text { to } 1.06)\end{array}$} & \multirow{4}{*}{$\begin{array}{l}2849 \\
(11 \mathrm{RCTS})\end{array}$} & \multirow{4}{*}{$\begin{array}{l}\oplus \oplus \oplus \oplus \bullet \\
{ }_{\text {MODERATE }}^{2,3}\end{array}$} \\
\hline & 95 per 1000 & $\begin{array}{l}79 \text { per } 1000 \\
(63 \text { to } 101)\end{array}$ & & & \\
\hline & \multicolumn{2}{|l|}{ Moderate } & & & \\
\hline & 72 per 1000 & $\begin{array}{l}59 \mathrm{per} 10000 \\
(47 \text { to } 76)\end{array}$ & & & \\
\hline \multicolumn{6}{|c|}{$\begin{array}{l}\text { 9Enteral or parenteral route } \\
1 \text { Total sample size } 72 \\
2 \text { Unexplained heterogeneity } \\
3 \text { Funnel plot asymmetry }\end{array}$} \\
\hline
\end{tabular}




\section{B A C K G R O U N D}

Glutamine is the most abundant amino acid in plasma and muscle in humans (Bergström 1974). Under normal conditions glutamine is the preferred respiratory fuel for rapidly proliferating cells such as enterocytes and lymphocytes (Windmueller 1982; Newsholme 1985). It is a regulator of acid-base balance via ammonium, as well as an important precursor of nucleic acids, nucleotides, amino sugars and protein (Krebs 1980).

\section{Description of the intervention}

Endogenous biosynthesis of glutamine may be insufficient for tissue needs in states of metabolic stress. In these situations glutamine appears to be "conditionally essential" (Lacey 1990). Glutamine is abundant in human milk, but present only in much lower levels in infant formula and not present in standard parenteral nutrition solutions. It has been suggested that glutamine supplementation may benefit preterm infants.

\section{How the intervention might work}

In animal models of experimental enterocolitis, glutamine supplementation has been associated with reduced mucosal damage, improved nitrogen balance, lower rates of sepsis and higher levels of survival (Klimberg 1990; Rombeau 1990). In studies in adult humans, glutamine supplementation has been shown to attenuate gut atrophy in the fasting state, maintain ATP levels in oxidant injured cells, preserve immune cellularity of the gastrointestinal tract during prolonged parenteral feeding and reduce post-operative deterioration in gastrointestinal permeability and mucosal integrity (O'Dwyer 1989; Hinshaw 1990; Alverdy 1992; van der Hulst 1993). Parenteral glutamine in adults is well tolerated metabolically and appears to have no toxic effects (Ziegler 1990). The findings of systematic reviews of randomised controlled trials in adult surgical or critically ill patients suggest that glutamine supplementation reduces infectious complications and duration of hospital stay and may reduce mortality (Wischmeyer 2008; Avenell 2009). Systematic reviews of randomised controlled trials found that patients undergoing bone marrow transplantation who receive parenteral nutrition with glutamine versus standard parenteral nutrition have fewer episodes of invasive infection (Crowther 2009; Murray 2009). Larger trials of glutamine supplementation in these populations are ongoing.

\section{Why it is important to do this review}

Given the findings in studies with adult participants, it is reasonable to hypothesise that glutamine supplementation in preterm infants (particularly very preterm infants) might enhance gastrointestinal mucosal integrity, thus improving enteral feed tolerance, growth and development. Enhanced gastrointestinal barrier function and lymphocyte production might reduce the rate of late-onset invasive infection or necrotising enterocolitis (NEC), and so reduce mortality and adverse neurodevelopmental outcomes.

\section{OB JECTIVES}

Our objective was to determine the effects of glutamine supplementation on mortality and morbidity in preterm infants. We prespecified subgroup analyses of enteral and parenteral glutamine supplementation because evidence from systematic reviews of these interventions in adults suggests different effect sizes for various outcomes (Avenell 2009).

\section{METHODS}

\section{Criteria for considering studies for this review}

\section{Types of studies}

We included controlled trials using random or quasi-random participant allocation. Due to the nature of the intervention, we excluded cross-over trials.

Where trials were reported as abstracts only, we aimed to include them provided there was sufficient information to assess eligibility. We contacted the authors requesting further information if we could not decide after reading the abstract.

\section{Types of participants}

We included preterm infants (gestational age $<37$ weeks) admitted to neonatal intensive or special care units or comparable settings after birth. Where participants in a trial included both term and preterm infants, we sought subgroup data from the report or from the authors.

\section{Types of interventions}

Glutamine supplementation versus no supplementation, administered by the parenteral or enteral route, in addition to a standard nutrition regime.

\section{Types of outcome measures}

Studies were included in the review regardless of whether they reported all outcome measures. If a study did not report these outcomes we requested further information from the trial authors.

\section{Primary outcomes}

1. Death prior to hospital discharge.

2. Neurodevelopment:

a. Neurodevelopmental outcomes assessed using validated tools at $\geq 12$ months post term.

b. Classifications of disability, including non-ambulant cerebral palsy, developmental delay and auditory and visual impairment.

c. Cognitive and educational outcomes at $\geq 5$ years: intelligence quotient and indices of educational achievement measured using a validated tool (including school examination results).

\section{Secondary outcomes}

1. Invasive infection during hospital admission as determined by culture of bacteria or fungus from blood, cerebrospinal fluid, urine or from a normally sterile body space (number of participants per group with one or more episodes).

2. NEC during hospital admission including at least two of the following features:

a. Pneumatosis coli on abdominal radiograph.

b. Abdominal distension/abdominal radiograph with gaseous distension or frothy appearance of bowel lumen (or both).

c. Blood in stool.

d. Lethargy, hypotonia or apnoea (or combination of these). 
3. Growth during the trial period: weight gain (g/day or $\mathrm{g} / \mathrm{kg} /$ day), linear growth (mm/week), head growth ( $\mathrm{mm} /$ week), skinfold thickness growth (mm/week).

4. Days from birth to establish full enteral tube feeds (at least 150 $\mathrm{ml} / \mathrm{kg} /$ day), independently of parenteral fluids or nutrition.

5. Days from birth to discharge to home from hospital.

\section{Search methods for identification of studies}

We used the standard search strategy of the Cochrane Neonatal Review Group.

\section{Electronic searches}

We searched: the Cochrane Central Register of Controlled Trials (CENTRAL), EMBASE (OvidSP), Maternity and Infant Care (OvidSP), MEDLINE \& MEDLINE in process (OvidSP) and PubMed (until December 2015 updated from previous search in November 2011) using the combination of text words and MeSH terms described in Appendix 1. We did not apply language restrictions. Search filters were applied in EMBASE, MEDLINE and PubMed to limit retrieval to clinical trials.

We searched Clinical Trials.gov, metaRegister of Controlled Trials (mRCT), and the WHO International Clinical Trials Registry Platform (ICTRP) for ongoing and completed trials.

\section{Searching other resources}

We examined the reference lists of studies identified as potentially relevant. We also searched the abstracts from the annual meetings of the Pediatric Academic Societies (1993 to 2015), the European Society for Pediatric Research (1995 to 2014), the UK Royal College of Paediatrics and Child Health (2000 to 2015) and the Perinatal Society of Australia and New Zealand (2000 to 2014). We considered trials reported only as abstracts to be eligible if sufficient information was available, from the report or from contact with the authors, to fulfil the inclusion criteria.

\section{Data collection and analysis}

We used the standard methods of the Cochrane Neonatal Review Group.

\section{Selection of studies}

Two review authors screened the titles and abstracts of all studies identified by the search. We assessed the full texts of any potentially eligible reports and excluded those studies that did not meet all of the inclusion criteria. We discussed any disagreements until consensus was achieved.

\section{Data extraction and management}

We used a data collection form to aid extraction of relevant information from each included study. One author extracted the data and a second author checked the extracted data. Any disagreements were discussed until consensus was achieved. We contacted the investigators for further information if data from the trial reports were insufficient.

\section{Assessment of risk of bias in included studies}

We used the criteria and standard methods of the Cochrane Neonatal Review Group to assess the methodological quality of any included trials. Two authors conducted the assessment of risk of bias. We resolved disagreements by discussion. We requested additional information from the trial authors to clarify methodology and results if necessary.

We made explicit judgements about whether studies were at high risk of bias across four domains according to the criteria suggested in the Cochrane Handbook for Systematic Reviews of Interventions (Higgins 2011):

1. Random sequence generation - we categorised the method used to generate the allocation sequence as having:

- low risk - any truly random process, e.g. random number table, computer random number generator;

- high risk - any non-random process, e.g. odd or even date of birth, hospital or clinic record number; or

- unclear risk - no or unclear information provided.

2. Allocation concealment - we categorised the method used to conceal the allocation sequence as having:

- low risk - e.g. telephone or central randomisation, consecutively numbered sealed opaque envelopes;

- high risk - open random allocation, e.g. unsealed or non-opaque envelopes, alternation, assignment determined by date of birth; or

- unclear risk - no or unclear information provided.

3. Blinding - we assessed blinding of participants, clinicians and caregivers, and outcome assessors separately for different outcomes and categorised the methods as having:

- low risk;

- high risk; or

- unclear risk.

4. Incomplete outcome data - we described the completeness of data, including attrition and exclusions from the analysis for each outcome, and any reasons for attrition or exclusion, where reported. We assessed whether missing data were balanced across groups or were related to outcomes. Where sufficient information was reported or supplied by the trial authors, we planned to reinstate missing data in the analyses. We categorised completeness as having:

- low risk: $\leq 10 \%$ missing data;

- high risk: > 10\% missing data; or

- unclear risk: no or unclear information provided.

\section{Quality of evidence}

We assessed the quality of evidence for the main comparisons at the outcome level using the Grading of Recommendations Assessment, Development and Evaluation (GRADE) approach (Guyatt 2011a). This methodological approach considers evidence from randomised controlled trials as high quality that may be downgraded based on consideration of any of five areas: design (risk of bias), consistency across studies, directness of the evidence, precision of estimates and presence of publication bias. (Guyatt 2011a). The GRADE approach results in an assessment of the quality of a body of evidence in one of four grades: 1) High: We are very confident that the true effect lies close to that of the estimate of the effect; 2) Moderate: We are moderately confident in the effect 
estimate: The true effect is likely to be close to the estimate of the effect, but there is a possibility that it is substantially different; 3 ) Low: Our confidence in the effect estimate is limited: The true effect may be substantially different from the estimate of the effect; 4) Very Low: We have very little confidence in the effect estimate: The true effect is likely to be substantially different from the estimate of effect (Schünemann 2013).

Two review authors independently assessed the quality of the evidence found for outcomes identified as critical or important for clinical decision making: mortality and invasive infection.

In cases where we considered the risk of bias arising from inadequate concealment of allocation, randomised assignment, complete follow-up or blinded outcome assessment to reduce our confidence in the effect estimates, we downgraded the quality of evidence accordingly (Guyatt 2011b). Consistency was evaluated by similarity of point estimates, extent of overlap of confidence intervals and statistical criteria including measurement of heterogeneity $\left(I^{2}\right)$. The quality of evidence was downgraded when inconsistency across studies results was present being large and unexplained (some studies suggest important benefit and others no effect or harm without a clinical explanation) (Guyatt 2011d). Precision was assessed according with the 95\% confidence interval around the pooled estimation (Guyatt 2011c). When trials were conducted in populations other than the target population, we downgraded the quality of evidence because of indirectness (Guyatt 2011e).

The pooled estimates of the effects and $95 \%$ confidence intervals (Cl) with explicit judgments for each of the above aspects assessed were entered into the Guideline Development Tool, the software used to create Summary of Findings (SoF) tables (GRADEpro 2008). All judgements involving the assessment of the study characteristics described above were explained in foot notes or comments in the SoF table.

\section{Measures of treatment effect}

We calculated relative risk (RR) and risk difference (RD) for dichotomous data and weighted mean difference (WMD) for continuous data, with respective $95 \%$ confidence intervals $(\mathrm{Cl})$. We determined the number needed to treat for benefit (NNTB) or harm (NNTH) for a statistically significant difference in the RD.

\section{Dealing with missing data}

We requested outcome data from the trial investigators when these were unavailable in the report. Specifically, we sought unpublished data on the primary outcomes and on the incidence of NEC and invasive infection for all trials. Further information on methodology, especially with regard to the assessment of the risk of bias, was also requested from authors if necessary. The tables 'Characteristics of included studies' report which information was obtained from authors.

\section{Assessment of heterogeneity}

We examined the treatment effects of individual trials and heterogeneity between trial results by inspecting the forest plots if more than one trial was included in a meta-analysis. We calculated the $I^{2}$ statistic for each analysis to quantify inconsistency across studies and describe the percentage of variability in effect estimates that may be due to heterogeneity rather than sampling error. If substantial heterogeneity was detected $\left(I^{2}>50 \%\right)$, we explored the possible causes (for example, differences in study design, participants, interventions, or completeness of outcome assessments).

\section{Assessment of reporting biases}

We inspected a funnel plot for asymmetry if more than ten trials were included in a meta-analysis.

\section{Data synthesis}

We used a fixed-effect model for meta-analyses.

\section{Subgroup analysis and investigation of heterogeneity}

We planned the following subgroup analyses:

1. Route of administration of glutamine supplementation: enteral versus parenteral glutamine administration.

2. Trial setting (country): low- and middle-income versus high-income countries (see: http://data.worldbank.org/about/ country-classifications)

\section{RE S U L T S}

\section{Description of studies}

See: Included studies; Excluded studies.

\section{Results of the search}

The updated search identified one new eligible trial (Pawlik 2012). One publication of relevant follow-up data from van den Berg 2005 was identified and included in this review (de Kieviet 2012). Several other publications of follow-up data were also identified by the searches but were excluded as they did not report any of our prespecified outcomes in addition to data already included in this review.

The trial NCT00213668 was identified by our search of trial registers. Contact with the trial coordinator revealed that this trial has been completed, however no publication of relevant outcomes could be identified. NCT01263041 was also identified by our searches as potentially relevant. We were unable to determine who is responsible for this trial and hence do not know the current status of this trial. These trials may be included in an update of this review as results become available.

\section{Included studies}

We included 12 trials that fulfilled the eligibility criteria; nine singlecentre studies (Lacey 1996; Neu 1997; Thompson 2003; BoberOlesiñska 2005; van den Berg 2005; Korkmaz 2007; Mohamad Ikram 2011; Sevastiadou 2011; Pawlik 2012), one trial in two centres (Wang 2010) and two larger multi-centre trials (Vaughn 2003; Poindexter 2004).

\section{Participants}

A total of 2877 preterm infants participated in the included trials; $2082(72 \%)$ of these infants participated in the two largest trials (Vaughn 2003; Poindexter 2004). All participating infants were of very or extremely low birth weight and were recruited to a trial within the first few days of postnatal life. 


\section{Intervention}

Six trials assessed the effect of parenteral glutamine supplementation (Lacey 1996; Thompson 2003; Poindexter 2004; Bober-Olesiñska 2005; Wang 2010; Mohamad Ikram 2011). The other six trials examined the effect of enteral glutamine supplementation (Neu 1997; Vaughn 2003; van den Berg 2005; Korkmaz 2007; Sevastiadou 2011; Pawlik 2012).

\section{Outcomes}

Reported outcomes included mortality, the incidence of invasive infection, NEC, the duration of parenteral nutrition administration, time taken to establish full enteral nutrition, rate of weight gain and length of hospital admission. Poindexter 2004 and van den Berg 2005 reported neurodevelopmental outcomes at 18 and 24 months post term, respectively. van den Berg 2005 reported neurodevelopmental and cognitive outcomes at seven to eight years of age.

\section{Excluded studies}

See: Characteristics of excluded studies.

\section{Risk of bias in included studies}

\section{Allocation}

Eight trials reported adequate allocation concealment methods (randomisation in central pharmacy, computer generated sequence in sealed opaque envelopes; Neu 1997; Thompson 2003; Vaughn 2003; Poindexter 2004; Bober-Olesiñska 2005; van den Berg 2005; Wang 2010; Mohamad Ikram 2011). Two trials were likely to be "quasi-randomised" and did not report concealment of allocation (Lacey 1996; Korkmaz 2007). Two trial reports did not describe the randomisation and allocation procedure (Sevastiadou 2011; Pawlik 2012).

\section{Blinding}

All apart from two trial reports described the methods used for blinding of caregivers and investigators (Korkmaz 2007; Pawlik 2012).

\section{Incomplete outcome data}

Nine trials achieved complete or near-complete levels of followup and reported intention-to-treat analyses (Neu 1997; Thompson 2003; Vaughn 2003; Poindexter 2004; Bober-Olesiñska 2005; van den Berg 2005; Wang 2010; Sevastiadou 2011; Pawlik 2012). Two trials did not report the drop out rate (Korkmaz 2007; Mohamad Ikram 2011). Lacey 1996 reported post-recruitment withdrawal of nearly $50 \%$ of participants, mainly due to non-compliance with protocol.

\section{Effects of interventions}

See: Summary of findings for the main comparison Glutamine supplementation to prevent morbidity and mortality in preterm infants

\section{Glutamine supplementation versus no supplementation (parenteral or enteral route)}

\section{Primary outcomes}

\section{Death prior to hospital discharge (Analysis 1.1)}

None of the individual studies nor a meta-analyses of data from all trials showed a statistically significant difference (typical RR 0.97, $95 \% \mathrm{Cl} 0.80$ to 1.17 ; typical RD $0.00,95 \% \mathrm{Cl}-0.03$ to $0.02 ; 12$ studies, 2877 infants; Analysis 1.1). There was no evidence of statistical heterogeneity or funnel plot asymmetry (Figure 1). 
Figure 1. Funnel plot of comparison: 1 Glutamine supplementation versus no supplementation, outcome: 1.1 Death prior to hospital discharge.

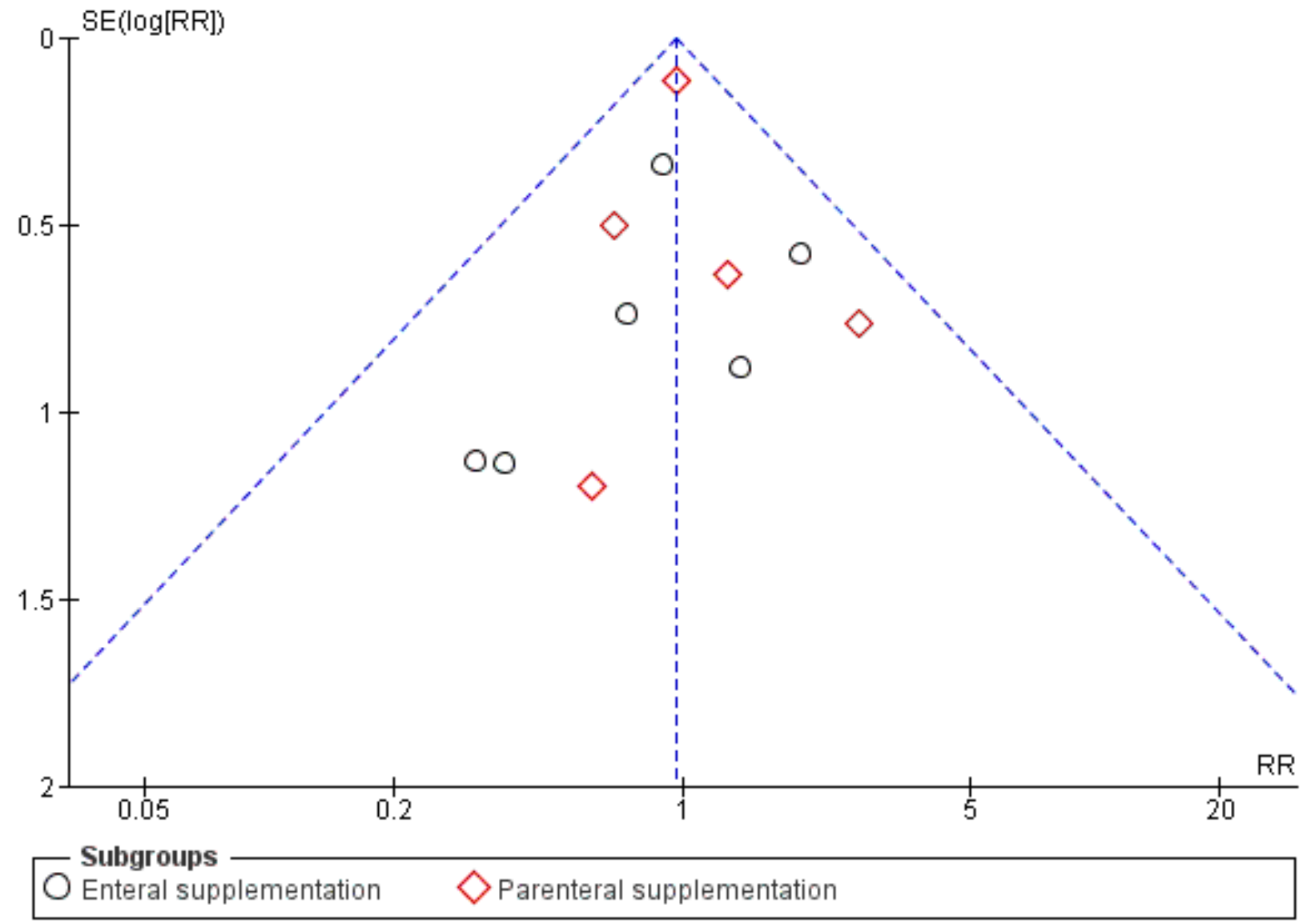

\section{Neurodevelopment (Analysis 1.2)}

Poindexter 2004 conducted follow-up assessments of about $89 \%$ of the surviving infants at 18 to 22 months post term. This included neurological examination and developmental assessment using Bayley Scales of Infant Development II (BSID-II) Mental, Motor and Behavior Rating Scales. The investigators reported that they did not find any statistically significant differences between the groups for any of the outcomes assessed but numerical data are not published or yet available. Thirty month follow-up on all of these infants was also planned. We could not find these data for inclusion in this review. They will be included in a future update if they become available.

van den Berg 2005 reported neurodevelopmental outcomes for infants aged two years post term. Outcomes assessed included the mental development index (MDI) and psychomotor development index (PDI) subscales of the BSID-II, incidence of cerebral palsy and visual and hearing impairment. No significant differences between the glutamine and the control groups were reported for any of these individual outcomes or for a composite of neurodevelopmental impairment consisting of any of the following: $\mathrm{MDI} \leq 85$, PDI $\leq$ 85 , cerebral palsy, blindness in one or both eyes or hearing loss requiring amplification ( $R R 1.07,95 \% \mathrm{Cl} 0.59$ to 1.92 ; $\mathrm{RD} 0.03,95 \%$ $\mathrm{Cl}-0.20$ to $0.25 ; 1$ study, 72 infants; Analysis 1.2). van den Berg 2005 reported follow-up assessments of 68 children aged 7 to 8 years. Four of these children had serious motor $(n=$ $2)$, hearing $(n=1)$, or visual $(n=1)$ difficulties which prevented them from participating; it is not known if these children received glutamine or placebo. Of the remaining 64 children, 30 had received glutamine after birth and 34 had received placebo. The trial did not show any significant differences in intelligence quotient, processing speed, attention level, working memory and parentand teacher-rated behavioural outcomes.

\section{Secondary outcomes}

\section{Invasive infection (Analysis 1.3)}

Data were available from eleven trials (Lacey 1996; Neu 1997; Thompson 2003; Vaughn 2003; Poindexter 2004; Bober-Olesiñska 2005; van den Berg 2005; Korkmaz 2007; Mohamad Ikram 2011; Sevastiadou 2011; Pawlik 2012). Two trials found a statistically significant lower incidence in infants who received glutamine (van den Berg 2005; Sevastiadou 2011), but none of the other trials nor a meta-analysis of all of the data found a statistically significant difference (typical RR $0.94,95 \% \mathrm{Cl} 0.86$ to 1.04 ; typical RD -0.02 , $95 \% \mathrm{Cl}-0.06$ to $0.01 ; 11$ studies, 2815 infants; Analysis 1.3). There was evidence of statistical heterogeneity $\left(I^{2}=58 \%\right)$ and funnel plot asymmetry (Figure 2). 
Figure 2. Funnel plot of comparison: 1 Glutamine supplementation versus no supplementation, outcome: 1.3 Invasive infection.

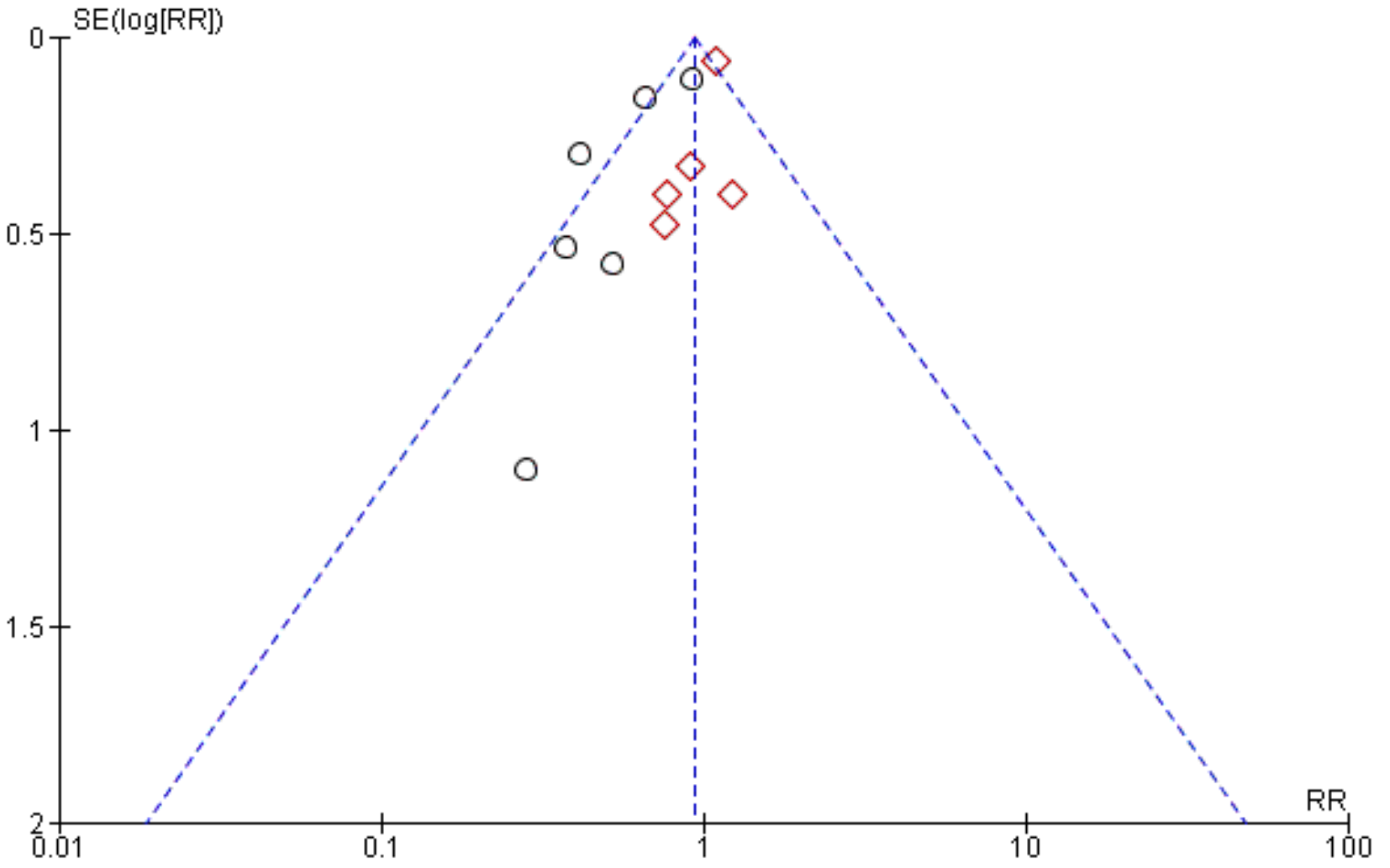

Subgroups

Enteral supplementation $\diamond$ Parenteral supplementation

\section{Necrotising enterocolitis (Analysis 1.4)}

None of the eleven individual studies that reported this outcome found a statistically significant difference (Lacey 1996; Neu 1997; Thompson 2003; Vaughn 2003; Poindexter 2004; Bober-Olesiñska 2005; van den Berg 2005; Korkmaz 2007; Mohamad Ikram 2011;
Sevastiadou 2011; Pawlik 2012). Meta-analysis did not reveal a statistically significant difference (typical RR $0.83,95 \% \mathrm{Cl} 0.66$ to 1.06; typical RD $-0.02,95 \% \mathrm{Cl}-0.04$ to $0.00 ; 11$ studies, 2879 infants; Analysis 1.4). There was some evidence of statistical heterogeneity $\left(\mathrm{I}^{2}=31 \%\right)$, as well as funnel plot asymmetry (Figure 3 ). 
Figure 3. Funnel plot of comparison: 1 Glutamine supplementation versus no supplementation, outcome: 1.4 Necrotising enterocolitis.

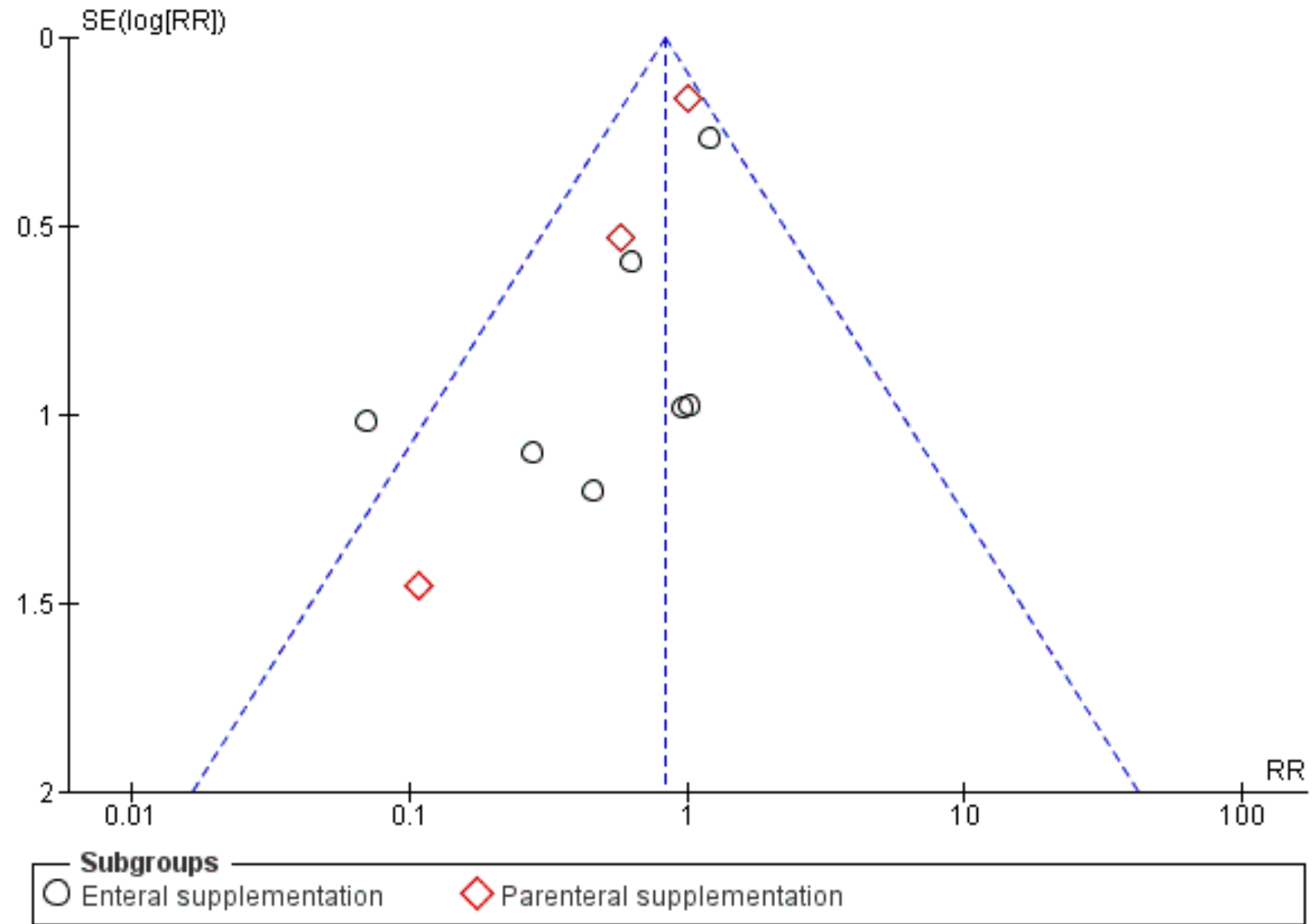

\section{Growth during the trial period (Analysis 1.5)}

Meta-analysis of data from three trials did not reveal a statistically significant difference in the rate of weight gain in grams/day during the study period (WMD $0.59,95 \% \mathrm{Cl}-1.42$ to 2.59 ; Analysis 1.5 ) There was evidence of statistical heterogeneity $\left(I^{2}=40 \%\right)$ (Analysis 1.5 ). Four trials reported no statistically significant differences in the rate of weight gain or mean weight at the end of the trial period but did not provide data that could be included in meta-analyses (Neu 1997; Vaughn 2003; Poindexter 2004; van den Berg 2005).

Korkmaz 2007 reported that the rate of gain in weight and length and head circumference was higher in the glutamine group than controls up to the end of the 120 day intervention period, but numerical data (including number of participants assessed at each monthly interval) were not available for inclusion in the metaanalysis.

\section{Days from birth to establish full enteral feeds (Analysis 1.6)}

Data were available from seven studies (Lacey 1996; Thompson 2003; Poindexter 2004; van den Berg 2005; Korkmaz 2007; Wang 2010; Mohamad Ikram 2011). Thompson 2003 reported a statistically significant shorter time to full enteral nutrition in the glutamine group while the other studies did not find any significant differences. Meta-analysis of data from all of these trials showed a statistically significant difference between glutamine and control groups in days to full enteral feeds (WMD $-1.68,95 \% \mathrm{Cl}-2.88$ to -0.48 ; Analysis 1.6). Statistical heterogeneity was not evident $\left(I^{2}=13 \%\right)$, nor was funnel plot asymmetry (Figure 4). 
Figure 4. Funnel plot of comparison: 1 Glutamine supplementation versus no supplementation, outcome: 1.6 Time to full enteral nutrition (days).

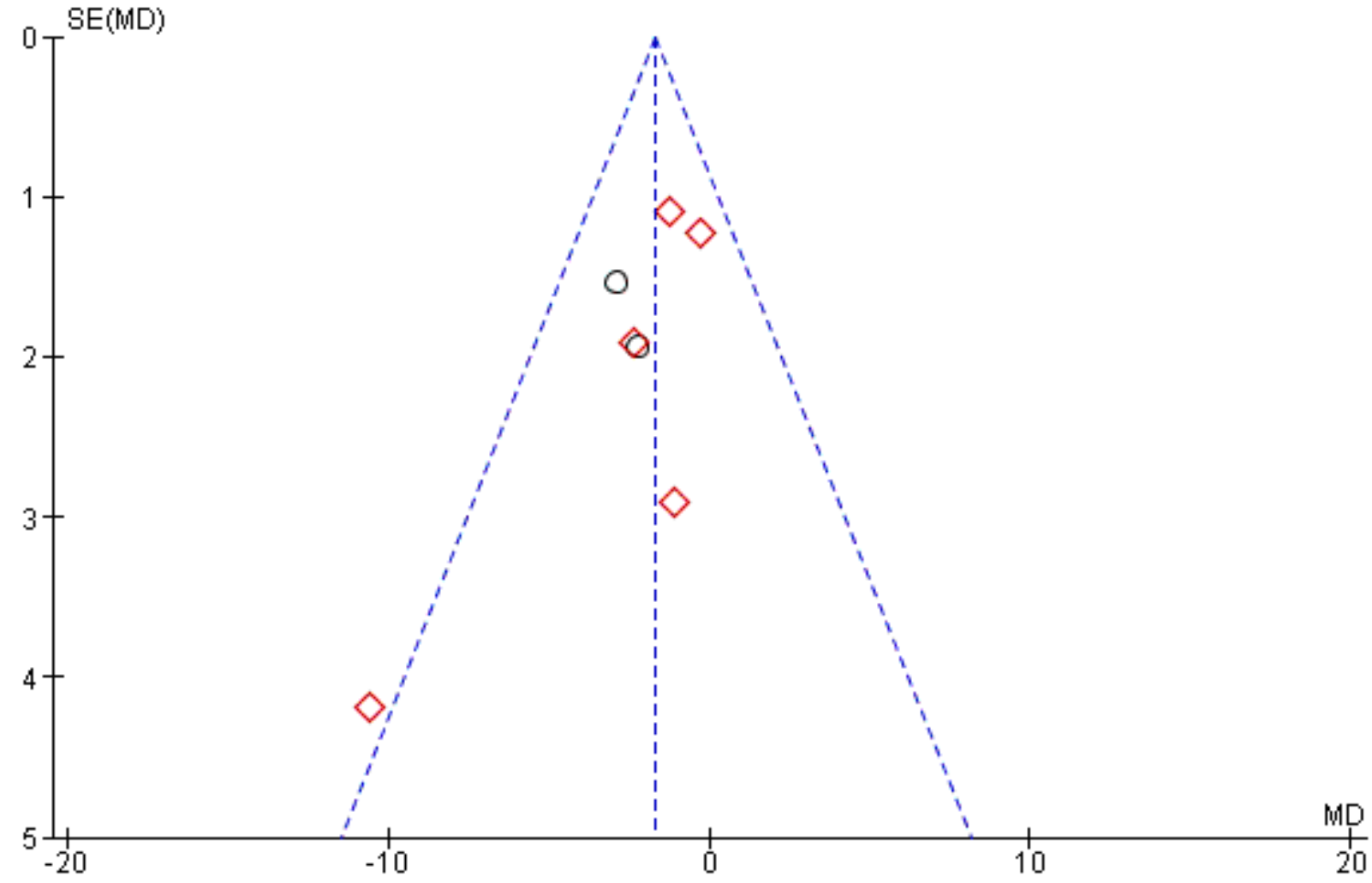

\section{Subgroups}

$\bigcirc$ Enteral supplementation $\diamond$ Parenteral supplementation

\section{Days from birth to discharge to home from hospital (Analysis 1.7)}

Data were available from eight trials (Lacey 1996; Thompson 2003; Vaughn 2003; Poindexter 2004; van den Berg 2005; Korkmaz 2007; Wang 2010; Mohamad Ikram 2011). None of the trials nor a meta-analysis of all data found a statistically significant difference between the glutamine and the control group in days from birth to discharge to home in days (WMD $-0.85,95 \% \mathrm{Cl}-3.39$ to 1.70 ; Analysis 1.7). Statistical heterogeneity was not evident $\left(I^{2}=0 \%\right)$, nor was funnel plot asymmetry (Figure 5). 
Figure 5. Funnel plot of comparison: 1 Glutamine supplementation versus no supplementation, outcome: 1.7 Duration of hospital stay (days).

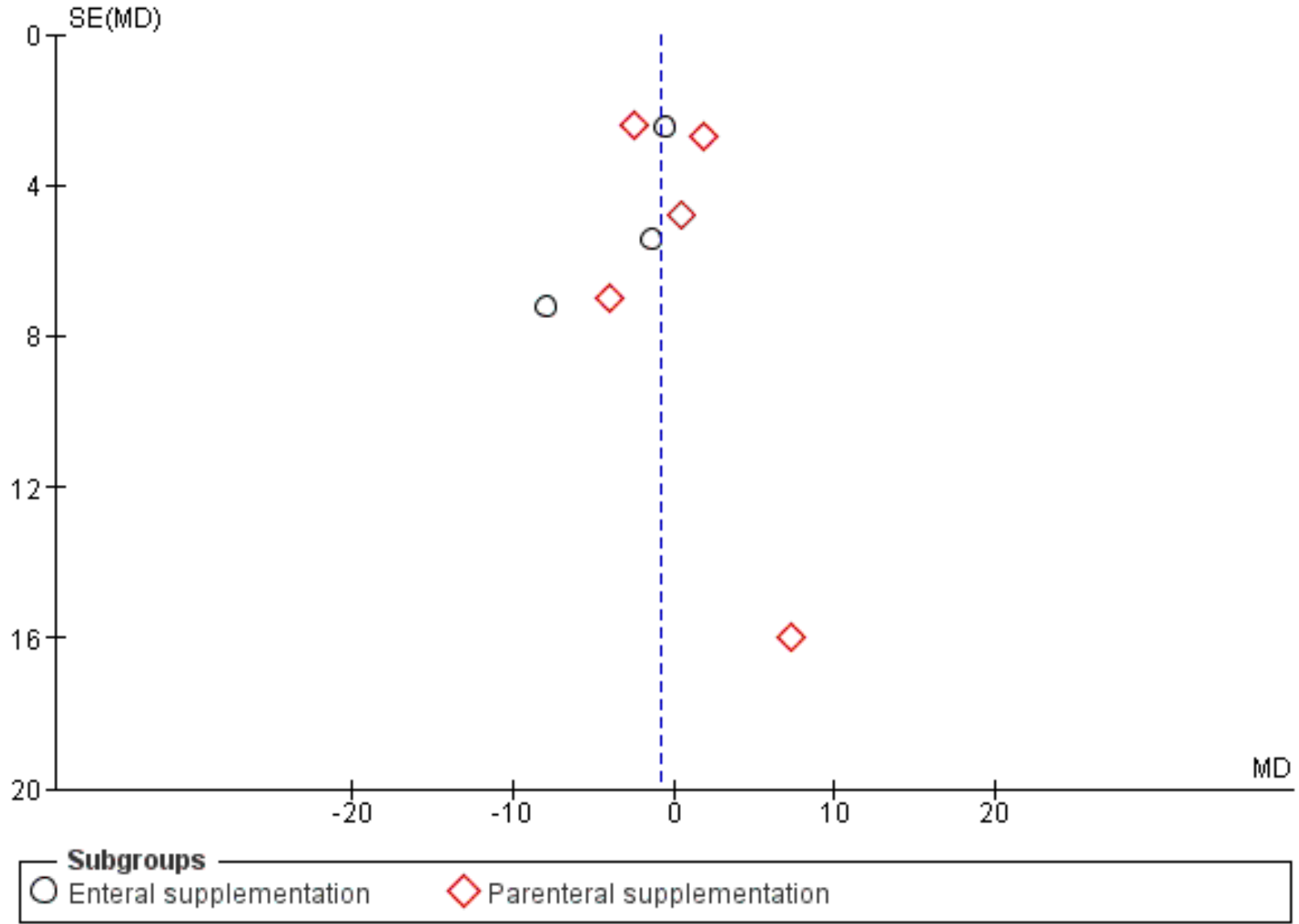

\section{Subgroup analyses}

\section{Enteral glutamine supplementation}

Six trials examined the effect of enteral glutamine supplementation (Neu 1997; Vaughn 2003; van den Berg 2005; Korkmaz 2007; Sevastiadou 2011; Pawlik 2012). Meta-analysis of the available data did not show statistically significant effects on mortality or NEC (Analysis 1.1; Analysis 1.4).

Meta-analysis showed a statistically significant lower incidence of invasive infection in the enteral glutamine supplemented group (typical RR $0.76,95 \% \mathrm{Cl} 0.64$ to 0.89 ; typical RD $-0.09,95 \% \mathrm{Cl}-0.14$ to -0.04 ; NNTB $11,05 \% \mathrm{Cl} 7$ to $25 ; 6$ studies, 1095 infants) (Analysis 1.3 ). The meta-analysis contained substantial statistical heterogeneity $\left(\mathrm{I}^{2}=56 \%\right)$ which remained in a sensitivity analysis in which the quasi-randomised trial was omitted (Korkmaz 2007).

Meta-analysis of data from two trials (van den Berg 2005; Korkmaz 2007) showed a statistically significant difference in time to reach full enteral feeds (WMD -2.63 days, $95 \% \mathrm{Cl}-4.99$ to -0.27 ) (Analysis 1.6). Meta-analysis of three trials (Vaughn 2003; van den Berg 2005; Korkmaz 2007) did not find a statistically significant difference in duration of hospital stay (Analysis 1.7).

\section{Parenteral glutamine supplementation}

Six trials examined the effect of parenteral glutamine supplementation (Lacey 1996; Thompson 2003; Poindexter 2004; Bober-Olesiñska 2005; Wang 2010; Mohamad Ikram 2011). Metaanalyses did not detect any statistically significant effects on mortality, incidence of invasive infection, incidence of NEC, rate of weight gain, time to full enteral nutrition, or duration of hospital stay (Analysis 1.1; Analysis 1.3; Analysis 1.5; Analysis 1.6; Analysis 1.7). Substantial heterogeneity was not evident in any of these meta-analyses.

\section{Low- or middle-income countries (Analyses 2.1-2.6)}

Three of the trials were undertaken in middle-income countries: Turkey (Korkmaz 2007), Malaysia (Mohamad Ikram 2011), and China (Wang 2010). Meta-analyses did not detect any statistically significant effects on mortality (Analysis 2.1), incidence of invasive infection (Analysis 2.2), NEC (Analysis 2.3), rate of weight gain (Analysis 2.4), time to full enteral feeds (Analysis 2.5), or duration of hospital stay (Analysis 2.6). Statistical heterogeneity was not evident in any of these meta-analyses. 


\section{DISCUSSION}

\section{Summary of main results}

The major finding of this review of 12 randomised controlled trials is that glutamine supplementation does not have a statistically significant effect on mortality in preterm infants. The narrow $95 \% \mathrm{Cl}$ around the estimate of effect suggests that a modest but clinically important difference has not been missed. Data from three of the trials also indicate that glutamine supplementation does not have an important effect on neurodevelopmental outcomes. With regard to secondary outcomes, we did not find evidence of an effect on major neonatal morbidities including the rate of invasive infection and the incidence of NEC.

In a pre-specified subgroup analysis, we found that enteral (but not parenteral) glutamine supplementation resulted in a statistically significant reduction in the incidence of invasive infection. However, the meta-analysis contained substantial heterogeneity not explained by variation in study design and methodological quality (randomised versus quasi-randomised). In a meta-analysis of two trials, enteral glutamine supplementation resulted in a 2.6 days reduction in the time taken to achieve full enteral nutrition. Given the potential clinical importance of these findings, further evaluation of enteral glutamine supplementation may be merited as advocated by van Zwol 2011. Currently, two trials of enteral glutamine supplementation in preterm infants are ongoing and their findings may be incorporated into an update of this review (NCT00213668; NCT01263041).

\section{Quality of the evidence}

The interpretation of the review findings is limited by the existence of methodological weaknesses associated with the potential for bias in some of the trials (Figure 6). The main concern is lack of evidence of methods to preserve allocation concealment in four of the trials (Lacey 1996; Korkmaz 2007; Sevastiadou 2011; Pawlik 2012). However, in general the trials were of good quality and analyses with quasi-randomised trials omitted did not alter statistical heterogeneity or the overall size of the treatment effects. 
Figure 6. Risk of bias summary: review authors' judgements about each risk of bias item for each included study.

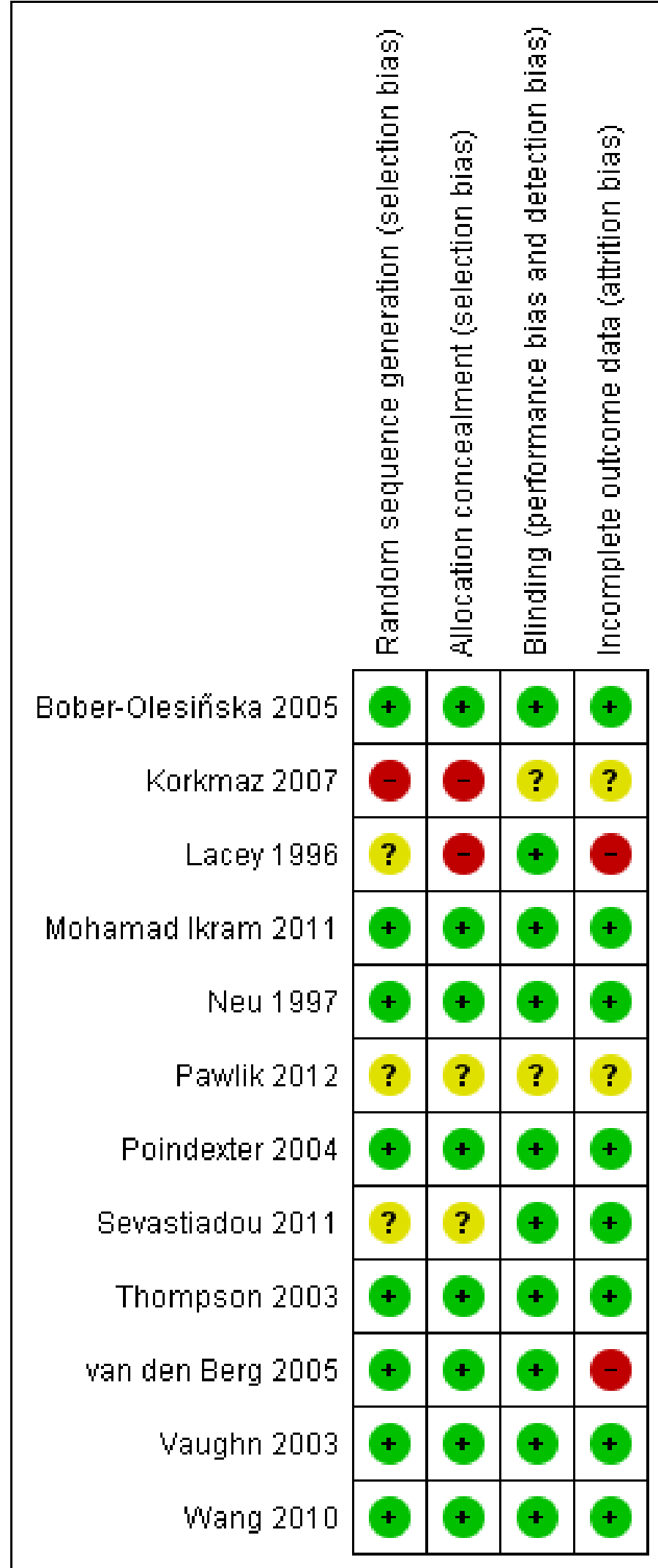


The other methodological limitation present in one of the trials was incomplete outcome assessment (Lacey 1996). This trial reported post-recruitment withdrawal of nearly $50 \%$ of participants, mainly due to non-compliance with protocol issues. Intention-to-treat re-analysis was not possible. Removal of this trial in sensitivity analyses did not affect the level of heterogeneity or size of treatment effect.

\section{Potential biases in the review process}

The main concern with the review process is the possibility that the findings are subject to publication and other reporting biases; in other words, that there may be a greater availability of data for inclusion in meta-analyses from trials which reported statistically significant or clinically important effects (Hopewell 2007a; Hopewell 2007b; Hopewell 2009). We attempted to minimise this threat by searching the proceedings of the major international perinatal conferences to identify trial reports that were not published in full form in academic journals (Young 2011). However, we cannot be sure that other trials have not been undertaken but not reported, and the concern remains that such trials are less likely than published trials to have detected statistically significant or clinically important effects. Some of the meta-analyses that we performed demonstrated funnel plot asymmetry consistent with possible publication or reporting bias (Figure 2).

\section{Agreements and disagreements with other studies or reviews}

The biologically plausible effects of glutamine supplementation relate to its role in the repair and growth of rapidly dividing cells. This action is consistent with the evidence of benefit of glutamine supplementation in critically ill adult patients (Wischmeyer 2008; Avenell 2009). Although the population of preterm infants who participated in the trials identified in this review were all of very low birth weight (and of extremely low birth weight in the largest trial), it may be that any benefits of glutamine supplementation are confined to those infants who are critically ill, for example with severe gastrointestinal disease such as NEC. Glutamine supplementation may be beneficial in the recovery phase of these illnesses when infants are severely metabolically compromised and glutamine availability is rate-limiting for tissue repair (Brown 2014). Additionally, many of the participating infants in the included trials may not have been truly glutamine-deficient as they received glutamine from breast milk, or received glutamate (a precursor for glutamine) from milk, formula, or parenteral nutrition.

\section{AUTHORS' CONCLUSIONS}

\section{Implications for practice}

The available data from randomised controlled trials suggests that the routine use of glutamine supplementation does not have an important effect on mortality or neonatal morbidity in preterm infants. Some limited evidence exists that enteral glutamine supplementation reduces the time to reach full enteral nutrition and the rate of late-onset invasive infection in preterm infants; this finding should be interpreted with caution because of the potential for bias in the included trials.

\section{Implications for research}

Follow-up of infants who participated in the trials identified in this review might provide further data on the effect of this intervention on growth through later childhood, specifically later neurodevelopmental outcomes. Further evaluation of routine parenteral glutamine supplementation in preterm infants is unlikely to be considered a research priority, but this review does provide some support for further trials of enteral glutamine supplementation to be undertaken (van Zwol 2011). It may also be appropriate to focus research effort on assessing the effect of glutamine supplementation as a treatment for preterm infants with severe gastrointestinal disease (Brown 2014).

\section{ACKNOWLEDGEMENTS}

We thank Melissa Harden (Centre for Reviews and Dissemination, University of York) for revising and running the electronic search.

We are very grateful to Drs Brenda Poindexter, Reece Clark, Ruurd van Elburg, Bober-Olesiñska, Ilias Mohamad Ikram, Ayse Korkmaz and Eleftheria Roma-Giannikou for supporting this Cochrane review by discussing aspects of their published findings and for sharing unpublished data (Poindexter 2004; van den Berg 2005; Vaughn 2003; Bober-Olesiñska 2005; Mohamad Ikram 2011; Korkmaz 2007; Sevastiadou 2011).

Editorial support of the Cochrane Neonatal Review Group has been funded with Federal funds from the Eunice Kennedy Shriver National Institute of Child Health and Human Development, National Institutes of Health, Department of Health and Human Services, USA, under Contract No. HHSN275201100016C. 


\section{R E F E R E N C E S}

\section{References to studies included in this review}

Bober-Olesiñska 2005 \{published data only\}

Bober-Olesiñska K, Kornacka MK. Effects of glutamine supplemented parenteral nutrition on the incidence of necrotizing enterocolitis, nosocomial sepsis and length of hospital stay in very low birth weight infants. Medycyna Wieku Rozwojowego 2005;9:325-33.

\section{Korkmaz 2007 \{published data only\}}

Korkmaz A, Yurdakök M, Yiğit S, Tekinalp G. Long-term enteral glutamine supplementation in very low birth weight infants: effects on growth parameters. Turkish Journal of Pediatrics 2007;49:37-44. [PUBMED: 17479642]

\section{Lacey 1996 \{published data only\}}

Lacey JM, Crouch JB, Benfell K, Ringer SA, Wilmore CK, Maguire D, Wilmore DW. The effects of glutamine-supplemented parenteral nutrition in premature infants. Journal of Parenteral and Enteral Nutrition 1996;20:74-80. [PUBMED: 8788268]

\section{Mohamad Ikram 2011 \{published and unpublished data\}}

Mohamad Ikram I, Quah BS, Noraida R, Djokomuljanto S, Faris Irfan CY, Van Rostenberghe $\mathrm{H}$. A randomised controlled trial of glutamine-enriched neonatal parenteral nutrition in Malaysia. Singapore Medical Journal 2011;52:356-60. [PUBMED: 21633770]

\section{Neu 1997 \{published data only\}}

Dallas MJ, Bowling D, Roig JC, Auestad N, Neu J. Enteral glutamine supplementation for very-low-birth-weight infants decreases hospital costs. Journal of Parenteral and Enteral Nutrition 1998;22:352-6. [PUBMED: 9829607]

* Neu J, Roig JC, Meetze WH, Veerman M, Carter C, Millsaps M, et al. Enteral glutamine supplementation for very low birth weight infants decreases morbidity. Journal of Pediatrics 1997;131:691-9. [PMID: 9403648 ]

Roig JC, Meetze WH, Auestad N, Jasionowski T, Veerman M, McMurray CA, et al. Enteral glutamine supplementation for the very low birthweight infant: plasma amino acid concentrations. Journal of Nutrition 1996;126:1115S-20S. [PUBMED: 8642443]

Pawlik 2012 \{published data only (unpublished sought but not used)\}

Pawlik D, Lauterbach R, Hurkala J, Radziszewska R. The effects of enteral administration of glutamine enriched solution in very low birth weight infants on reducing the symptoms of feeding intolerance. A prospective, randomised pilot study [Wplyw enteralnej podazy roztworu wzbogaconego glutamina, u noworodkow z bardzo mala urodzeniowa masa ciala, na organiczenie objawow nietolerancji karmienia. Prospektywne, randomizowane badanie pilotazowe]. Medycyna Wieku Rozwojowego 2012;XVI(3):206-11. [PUBMED: 23378398]

\section{Poindexter 2004 \{published data only\}}

Poindexter B, Langer J, Dusick A, Ehrenkranz R, for the NICHD Neonatal Research Network. Early provision of parenteral amino acids in ELBW infants- relationship with growth and neurodevelopmental outcome at 18 months corrected age. Pediatric Research. 2004; Vol. 55:382A.

* Poindexter BB, Ehrenkrantz RA, Stoll BJ, Wright LL, Poole WK, Oh W, et al. Parenteral glutamine supplementation does not reduce the risk of morbidity or late-onset sepsis in extremelylow-birthweight infants. Pediatrics 2004;113:1209-15. [PMID: 15121931]

Poindexter BB, Ehrenkranz RA, Stoll BJ, Koch MA, Wright LL, Oh W, et al. Effect of parenteral glutamine supplementation on plasma amino acid concentrations in extremely lowbirth-weight infants. American Journal of Clinical Nutrition 2003;77(3):737-43. [PUBMED: 12600870]

Poindexter BB, Langer JC, Dusick AM, Ehrenkranz RA. Early provision of parenteral amino acids in extremely low birth weight infants: relation to growth and neurodevelopmental outcome. Journal of Pediatrics 2006;148(3):300-5. [PUBMED: 16615955]

\section{Sevastiadou 2011 \{published data only\}}

Sevastiadou S, Malamitsi-Puchner A, Costalos C, Skouroliakou M, Briana DD, Antsaklis A, et al. The impact of oral glutamine supplementation on the intestinal permeability and incidence of necrotizing enterocolitis/septicemia in premature neonates. Journal of Maternal-Fetal Medicine 2011;24:1294-300. [PUBMED: 21463215]

\section{Thompson 2003 \{published data only\}}

Thompson SW, McClure BG, Tubman TRJ. A randomised controlled trial of parenteral glutamine in ill very low birth weight neonates. Journal of Parenteral and Enteral Nutrition 2003;37:550-3. [PUBMED: 14581795]

\section{van den Berg 2005 \{published data only\}}

de Kieviet JF, Oosterlaan J, Vermeulen RJ, Pouwels PJW, Lafeber HN, van Elburg RM. Effects of glutamine on brain development in very preterm children at school age. Pediatrics 2012;130(5):e1121-7. [PUBMED: 23071202]

de Kieviet JF, Oosterlaan J, van Zwol A, Boehm G, Lafaber HN, van Elburg RM. Effects of neonatal enteral glutamine supplementation on cognitive, motor, and behavioural outcomes in very preterm and/or very low birth weight children at school age. British Journal of Nutrition 2012;108(12):2215-20. [PUBMED: 22313936]

de Kieviet JF, Vujik PJ, van den Berg A, Lafaber HN, Oosterlaan J, van Elburg RM. Glutamine effects on brain growth in very preterm children in the first year of life. Clinical Nutrition 2014;33(1):69-74. [PUBMED: 23582234]

van Zwol A, van den Berg A, Huisman J, Vermeulen RJ, Fetter WP, Twisk JW, et al. Neurodevelopmental outcomes of very low-birth-weight infants after enteral glutamine supplementation in the neonatal period. Acta Paediatrica 2008;97:562-7. [PUBMED: 18394100]

van den Berg A, Fetter WP, Westerbeek EA, van der Vegt IM, van der Molen HR, van Elburg RM. The effect of glutamine- 
enriched enteral nutrition on intestinal permeability in verylow-birth-weight infants: a randomized controlled trial. Journal of Parenteral and Enteral Nutrition 2006;30:408-14.

van den Berg A, van Elburg RM, Twisk JW, Fetter WP. Glutamineenriched enteral nutrition in very low birth weight infants. Design of a double-blind randomised controlled trial [ISRCTN73254583]. BMC Pediatrics 2004;4:17.

* van den Berg A, van Elburg RM, Westerbeek EA, Twisk JW, Fetter WP. Glutamine-enriched enteral nutrition in very-lowbirth-weight infants and effects on feeding tolerance and infectious morbidity: a randomized controlled trial. American Journal of Clinical Nutrition 2005;81:1397-404. [PUBMED: 15941893]

\section{Vaughn 2003 \{published data only\}}

Vaughn P, Thomas P, Clark R, Neu J. Enteral glutamine supplementation and morbidity in low birth weight infants. Journal of Pediatrics 2003;142:662-8. [PUBMED: 12838195]

\section{Wang 2010 \{published data only\}}

Wang Y, Cai W, Tao YX, Tang QY, Feng Y, Wu J. Clinical outcomes of glutamine supplementation in neonates. Chinese Journal of Clinical Nutrition 2009;17:259-63.

Wang Y, Cai W, Tao YX, Tang QY, Feng Y, Wu J. Glutamine supplementation in preterm infants receiving parenteral nutrition leads to an early improvement in liver function. Asia Pacific Journal of Clinical Nutrition 2013;22(4):530-6. [PUBMED: 24231012]

* Wang Y, Tao YX, Cai W, Tang QY, Feng Y, Wu J. Protective effect of parenteral glutamine supplementation on hepatic function in very low birth weight infants. Clinical Nutrition 2010;29:307-11. [PUBMED: 20416995]

\section{References to studies excluded from this review}

Barbosa 1999 \{published data only\}

Barbosa E, Moreira AM, Goes JE, Faintuch J. Pilot study with a glutamine-supplemented enteral formula in critically ill infants. Revista do Hospital dos Clinicas 1999;54(1):21-4. [PUBMED: 10488597]

\section{Li 2007 \{published data only\}}

Li ZH, Wang DH, Dong M. Effect of parenteral glutamine supplementation in premature infants. Chinese Medical Journal 2007;120:140-4.

\section{Strujis 2013 \{published data only\}}

Strujis MC, Schaible T, van Elburg RM, Debauche C, te Best H, Tibboel D. Efficacy and safety of a parenteral amino acid solution containing alanyl-glutamine versus standard solution in infants: a first-in-man randomised double-blind trial. Clinical Nutrition 2013;32(3):331-7. [PUBMED: 23562219]

\section{References to ongoing studies}

NCT00213668 \{published data only\}

Effect of (enteral) Glutamine on Gastric Emptying and Length of Parenteral Nutrition in Premature Neonates. ClinicalTrials.gov 2010.

\section{NCT01263041 \{published data only\}}

Effect of L-arginine and Glutamine on Preterm (preterm). ClinicalTrials.gov 2011.

\section{Additional references}

\section{Alverdy 1992}

Alverdy JA, Aoys E, Weiss-Carrington P, Burke DA. The effect of glutamine-enriched TPN on gut immune cellularity. Journal of Surgical Research 1992;52:34-8. [PUBMED: 1548865]

\section{Avenell 2009}

Avenell A. Hot topics in parenteral nutrition. Current evidence and ongoing trials on the use of glutamine in critically-ill patients and patients undergoing surgery. Proceedings of the Nutrition Society 2009;68:261-8. [PUBMED: 19490739]

\section{Bergström 1974}

Bergström J, Fürst P, Norée LO, Vinnars E. Intracellular free amino acid concentrations in human muscle tissue. Journal of Applied Physiology 1974;36:693-7. [PUBMED: 4829908]

\section{Brown 2014}

Brown JV, Moe-Byrne T, McGuire W. Glutamine supplementation for young infants with severe gastrointestinal disease. Cochrane Database of Systematic Reviews 2014, Issue 12. [DOI: 10.1002/14651858.CD005947.pub4]

\section{Crowther 2009}

Crowther M, Avenell A, Culligan DJ. Systematic review and meta-analyses of studies of glutamine supplementation in haematopoietic stem cell transplantation. Bone Marrow Transplantation 2009;44:413-25. [PUBMED: 19270730]

\section{de Kieviet 2012}

de Kieviet JF, Oosterlaan J, van Zwol A, Boehm G, Lafaber HN, van Elburg RM. Effects of neonatal enteral glutamine supplementation on cognitive, motor, and behavioural outcomes in very preterm and/or very low birth weight children at school age. British Journal of Nutrition 2012;108(12):2215-20. [PUBMED: 22313936]

\section{GRADEpro 2008 [Computer program]}

Brozek J, Oxman A, Schünemann H. GRADEpro [Version 3.2 for Windows]. The GRADE Working Group, 2008.

\section{Guyatt 2011a}

Guyatt G, Oxman AD, Akl EA, Kunz R, Vist G, Brozek J, et al. GRADE guidelines: 1 . Introduction-GRADE evidence profiles and summary of findings tables. Journal of Clinical Epidemiology 2011;64(4):383-94. [PUBMED: 21195583] 


\section{Guyatt 2011b}

Guyatt GH, Oxman AD, Vist G, Kunz R, Brozek J, Alonso-Coello P, et al. GRADE guidelines: 4 . Rating the quality of evidence-study limitations (risk of bias). Journal of Clinical Epidemiology 2011;64(4):407-15. [PUBMED: 21247734]

\section{Guyatt 2011c}

Guyatt GH, Oxman AD, Kunz R, Brozek J, Alonso-Coello P, Rind $D$, et al. GRADE guidelines 6 . Rating the quality of evidence--imprecision. Journal of Clinical Epidemiology 2011;64(12):1283-93. [PUBMED: 21839614]

\section{Guyatt 2011d}

Guyatt GH, Oxman AD, Kunz R, Woodcock J, Brozek J, Helfand M, et al. GRADE guidelines: 7 . Rating the quality of evidence--inconsistency. Journal of Clinical Epidemiology 2011;64(12):1294-302. [PUBMED: 21803546]

\section{Guyatt 2011e}

Guyatt GH, Oxman AD, Kunz R, Woodcock J, Brozek J, Helfand M, et al. GRADE guidelines: 8 . Rating the quality of evidence--indirectness. Journal of Clinical Epidemiology 2011;64(12):1303-10. [PUBMED: 21802903]

\section{Higgins 2011}

Higgins JPT, Green S (editors). Cochrane Handbook for Systematic Reviews of Interventions Version 5.1.0 [updated March 2011]. The Cochrane Collaboration, 2011. Available from www.cochrane-handbook.org.

\section{Hinshaw 1990}

Hinshaw DB, Burger JM. Protective effect of glutamine on endothelial cell ATP in oxidant injury. Journal of Surgical Research 1990;49:222-7.

\section{Hopewell 2007a}

Hopewell S, Clarke M, Stewart L, Tierney J. Time to publication for results of clinical trials. Cochrane Database of Systematic Reviews 2007, Issue 2. [DOI: 10.1002/14651858.MR000011.pub2]

\section{Hopewell 2007b}

Hopewell S, McDonald S, Clarke M, Egger M. Grey literature in meta-analyses of randomized trials of health care interventions. Cochrane Database of Systematic Reviews 2007, Issue 2. [DOI: 10.1002/14651858.MR000010.pub3]

\section{Hopewell 2009}

Hopewell S, Loudon K, Clarke MJ, Oxman AD, Dickersin K. Publication bias in clinical trials due to statistical significance or direction of trial results. Cochrane Database of Systematic Reviews 2009, Issue 1. [DOI: 10.1002/14651858.MR000006.pub3]

\section{Klimberg 1990}

Klimberg VS, Salloum RM, Kasper M, Plumley DA, Dolson DJ, Hautamaki RD, et al. Oral glutamine accelerates healing of the small intestine and improves outcome after whole abdominal radiation. Archives of Surgery 1990;125:1040-5. [PUBMED: 2378557]

\section{Krebs 1980}

Krebs H. Glutamine metabolism in the animal body. In: Mora J, Palacios R editor(s). Glutamine: metabolism, enzymology and regulation. New York: Academic Press, 1980:319-29.

\section{Lacey 1990}

Lacey J, Wilmore DW. Is glutamine a conditionally essential amino acid?. Nutrition Reviews 1990;48:297-309. [PUBMED: 2080048]

\section{Lefebvre 2008}

Lefebvre C, Eisinga A, McDonald S, Paul N. Enhancing access to reports of randomised trials published world-wide - the contribution of EMBASE records to the Cochrane Central Register of Controlled Trials (CENTRAL) in the Cochrane Library. Emerg Themes Epidemiol 2008;5:13. [PUBMED: 18826567]

\section{Lefebvre 2011}

Lefebvre C, Manheimer E, Glanville J. Chapter 6: Searching for studies. In: Higgins JPT, Green S editor(s). Cochrane Handbook for Systematic Reviews of Interventions. Version 5.1.0. The Cochrane Collaboration, 2011.

\section{Murray 2009}

Murray SM, Pindoria S. Nutrition support for bone marrow transplant patients. Cochrane Database of Systematic Reviews 2009, Issue 1. [DOI: 10.1002/14651858.CD002920.pub3]

\section{Newsholme 1985}

Newsholme EA, Crabtree B, Ardawi MS. Glutamine metabolism in lymphocytes: its biochemical, physiological and clinical importance. Quarterly Journal of Experimental Physiology 1985;70:473-89. [PUBMED: 3909197]

\section{O'Dwyer 1989}

O'Dwyer ST, Smith RJ, Hwang TL, Wilmore DW. Maintenance of small bowel mucosa with glutamine enriched parenteral nutrition. Journal of Parenteral and Enteral Nutrition 1989;13:579-85. [PUBMED: 2515303]

\section{Rombeau 1990}

Rombeau JL. A review of the effects of glutamine-enriched diets on experimentally induced enterocolitis. Journal of Parenteral and Enteral Nutrition 1990;14:100S-105S. [PUBMED: 2119454]

\section{Schünemann 2013}

Schünemann H, Brożek J, Guyatt G, Oxman A, editors. GWG. GRADE handbook for grading quality of evidence and strength of recommendations. Available from www.guidelinedevelopment.org/handbook Updated October 2013.

\section{van der Hulst 1993}

Van der Hulst RRW, van Kreel BK, von Meyenfeldt MF, Brummer RJM, Arends JW, Deutz NEP, et al. Glutamine and the preservation of gut integrity. Lancet 1993;334:1363-5. [PUBMED: 8098788] 


\section{van Zwol 2011}

van Zwol A, Neu J, van Elburg RM. Long-term effects of neonatal glutamine-enriched nutrition in very-low-birth-weight infants. Nutrition Reviews 2011;69:2-8. [PUBMED: 21198630]

\section{Windmueller 1982}

Windmueller HG. Glutamine utilization by the small intestine. Advances in Enzymology and Related Areas of Molecular Biology 1982;53:201-37. [PUBMED: 7036679]

\section{Wischmeyer 2008}

Wischmeyer PE. Glutamine: role in critical illness and ongoing clinical trials. Current Opinion in Gastroenterology 2008;24:190-7. [PUBMED: 18301270]

\section{Young 2011}

Young T, Hopewell S. Methods for obtaining unpublished data. Cochrane Database of Systematic Reviews 2011, Issue 11. [DOI: 10.1002/14651858.MR000027.pub2]

\section{Ziegler 1990}

Ziegler TR, Benfell K, Smith RJ, Young LS, Brown E, FerrariBaliviera E, et al. Safety and metabolic effects of L-glutamine administration in humans. Journal of Parenteral and Enteral Nutrition 1990;14:137S-146S. [PUBMED: 2119459]

\section{References to other published versions of this review Moe-Byrne 2012}

Moe-Byrne T, Brown JVE, McGuire W. Glutamine supplementation to prevent morbidity and mortality in preterm infants. Cochrane Database of Systematic Reviews 2012, Issue 3. [DOI: 10.1002/14651858.CD001457.pub4]

\section{Tubman 1999}

Tubman TRJ, Thompson SW. Glutamine supplementation to prevent morbidity in preterm infants. Cochrane Database of Systematic Reviews 1999, Issue 2. [DOI: 10.1002/14651858.CD001457]

\section{Tubman 2001}

Tubman TRJ, Thompson SW. Glutamine supplementation to prevent morbidity and mortality in preterm infants. Cochrane Database of Systematic Reviews 2001, Issue 4. [DOI: 10.1002/14651858.CD001457.pub2]

\section{Tubman 2005}

Tubman TR, Thompson SW, McGuire W. Glutamine supplementation to prevent morbidity and mortality in preterm infants. Cochrane Database of Systematic Reviews 2005, Issue 1. [DOI: 10.1002/14651858.CD001457.pub2]

\section{Tubman 2008}

Tubman TR, Thompson SW, McGuire W. Glutamine supplementation to prevent morbidity and mortality in preterm infants. Cochrane Database of Systematic Reviews 2008, Issue 1. [DOI: 10.1002/14651858.CD001457.pub3]

* Indicates the major publication for the study

\section{CHARACTERISTICS OF STUDIES}

Characteristics of included studies [ordered by study ID]

Bober-Olesiñska 2005

\begin{tabular}{ll}
\hline Methods & Randomised controlled trial \\
\hline Participants & 55 very low birth weight infants \\
\hline $\begin{array}{ll}\text { Interventions } \\
\text { amino acid content }(n=25) \\
\text { Control: no added glutamine ( } n=30)\end{array}$ \\
\hline Outcomes & Invasive infection and rate of NEC \\
\hline Notes & Abstract in English. Article in Polish. Further information received courtesy of Dr Bober-Olesiñska. \\
\hline Risk of bias & Authors' judgement Support for judgement \\
\hline Bias & Low risk $\quad$ Computer-generated \\
\hline $\begin{array}{l}\text { Random sequence genera- } \\
\text { tion (selection bias) }\end{array}$ & \\
\hline
\end{tabular}


Bober-Olesiñska 2005 (Continued)

\begin{tabular}{lll}
$\begin{array}{l}\text { Allocation concealment } \\
\text { (selection bias) }\end{array}$ & Low risk & Sealed opaque envelopes \\
\hline $\begin{array}{l}\text { Blinding (performance } \\
\text { bias and detection bias) } \\
\text { All outcomes }\end{array}$ & Low risk & Blinding of intervention and outcome measurement
\end{tabular}

Incomplete outcome data Low risk Complete follow up assessment
(attrition bias)
All outcomes

\section{Korkmaz 2007}

\begin{tabular}{|c|c|}
\hline Methods & Quasi-randomised controlled trial \\
\hline \multirow[t]{2}{*}{ Participants } & 69 very low birth weight infants (appropriate birth weight for gestational age) \\
\hline & $\begin{array}{l}\text { Exclusion criteria: congenital malformations, chromosomal abnormalities, inherited metabolic dis- } \\
\text { eases, receipt of enteral feeding for }<1 \text { week or mechanical ventilation for }>4 \text { weeks, those developing } \\
\text { post-haemorrhagic hydrocephalus after grade III to IV intra-ventricular haemorrhage }\end{array}$ \\
\hline \multirow[t]{2}{*}{ Interventions } & $\begin{array}{l}\text { Treatment: enteral glutamine supplementation ( } 300 \mathrm{mg} / \mathrm{kg} / \text { day) between } 8-120 \text { days after birth }(\mathrm{n}= \\
\text { 36) }\end{array}$ \\
\hline & Control: sterile water $(n=33)$ \\
\hline \multirow[t]{4}{*}{ Outcomes } & $\begin{array}{l}\text { Growth parameters (weight, length, head circumference, left upper mid-arm circumference, left mid- } \\
\text { thigh circumference during trial period ( } 4 \text { months)) }\end{array}$ \\
\hline & Incidence of invasive infection \\
\hline & Time to full enteral nutrition \\
\hline & Duration of hospital stay \\
\hline \multirow[t]{2}{*}{ Notes } & Data on mortality and NEC incidence supplied by trial investigators \\
\hline & $\begin{array}{l}\text { Setting: Neonatal Intensive Care Unit and neonatal follow-up clinic of Hacettepe University, Ihsan Do- } \\
\text { gramaci Children's Hospital, Anakara, Turkey (early 2000s) }\end{array}$ \\
\hline
\end{tabular}

\section{Risk of bias}

\begin{tabular}{lll}
\hline Bias & Authors' judgement & Support for judgement \\
\hline $\begin{array}{l}\text { Random sequence genera- } \\
\text { tion (selection bias) }\end{array}$ & High risk & $\begin{array}{l}\text { Quasi-randomised allocation of participants according to the order of admis- } \\
\text { sion }\end{array}$ \\
\hline $\begin{array}{l}\text { Allocation concealment } \\
\text { (selection bias) }\end{array}$ & High risk & $\begin{array}{l}\text { Quasi-randomised allocation of participants according to the order of admis- } \\
\text { sion }\end{array}$ \\
\hline $\begin{array}{l}\text { Blinding (performance } \\
\text { bias and detection bias) } \\
\text { All outcomes }\end{array}$ & Unclear risk & Not described \\
\hline
\end{tabular}

Incomplete outcome data Unclear risk

Not reported, number presumed to be followed up: 36 and 33

(attrition bias)

All outcomes 
Lacey 1996

\begin{tabular}{ll}
\hline Methods & Randomised controlled trial \\
\hline Participants & 78 infants aged $<4$ days, receiving parenteral nutrition for $<3$ days \\
& Must have met $>5$ of the following criteria: birth weight $<1500$ g, gestational age $<32$ weeks, 5 -minute \\
& Apgar score $<6$, need for $>21 \%$ oxygen, need for ventilatory assistance, low blood pressure for age, sus- \\
pected intraventricular haemorrhage, presence of patent ductus arteriosus, presence of umbilical, ar- & terial and venous catheters and birth weight $<1000 \mathrm{~g}$
\end{tabular}

Interventions $\quad$ Treatment: glutamine added to parenteral nutrition solution $(\mathrm{n}=38)$

Control: parenteral nutrition without added glutamine $(n=39)$

Outcomes Time to full enteral feeds, duration of administration of parenteral nutrition, duration of mechanical
ventilation, average weight gain per day, duration of hospital stay

Notes $\quad$ Glutamine was added to parenteral nutrition at concentrations of between $15 \%$ and $25 \%$ weight per volume of the amino acid mix. The protocol specified that participating infants should continue to receive parenteral nutrition for at least seven days.

Setting: Brigham and Women's Hospital, Boston, USA (early 1990s)

\section{Risk of bias}

\begin{tabular}{lll}
\hline Bias & Authors' judgement & Support for judgement \\
\hline $\begin{array}{l}\text { Random sequence genera- } \\
\text { tion (selection bias) }\end{array}$ & Unclear risk & Not described \\
\hline $\begin{array}{l}\text { Allocation concealment } \\
\text { (selection bias) }\end{array}$ & High risk & $\begin{array}{l}\text { First four infants allocated to intervention group and subsequent participants } \\
\text { allocated by "balanced assignment" - unclear if this was concealed, may be } \\
\text { quasi-randomisation }\end{array}$ \\
\hline $\begin{array}{l}\text { Blinding (performance } \\
\text { bias and detection bias) }\end{array}$ & Low risk & $\begin{array}{l}\text { Investigators, nursing staff and dieticians blinded } \\
\text { All outcomes }\end{array}$ \\
\hline $\begin{array}{l}\text { Incomplete outcome data } \\
\text { (attrition bias) } \\
\text { All outcomes }\end{array}$ & High risk & $\begin{array}{l}\text { Of the } 78 \text { infants originally enrolled, } 34 \text { were subsequently excluded for the } \\
\text { following reasons: insufficient time on parenteral nutrition (8 treated and } 8 \\
\text { control), surgery or transfer (1 treated and } 3 \text { control), development of NEC (2 } \\
\text { treatment and } 2 \text { control) or death (5 treatment and } 4 \text { control). One was exclud- } \\
\text { ed as a "statistical outlier" (allocation not stated). We have not been able to re- } \\
\text { analyse the outcomes for all of the enrolled infants (intention-to-treat). }\end{array}$ \\
\hline
\end{tabular}

Mohamad Ikram 2011

\begin{tabular}{ll}
\hline Methods & Randomised controlled trial \\
\hline Participants & 154 newborn infants aged $<72$ hours and receiving parenteral nutrition \\
& $\begin{array}{l}\text { Exclusion criteria: chromosomal abnormalities or inborn metabolism errors, those born from consan- } \\
\text { guineous marriage and those anticipated to require }<48 \text { hours parenteral nutrition }\end{array}$
\end{tabular}

Interventions

Treatment: $20 \%$ glutamine solution added to standard parenteral nutrition $(\mathrm{n}=76)$ 
Mohamad Ikram 2011 (Continued)

Control: standard parenteral nutrition $(n=78)$

\begin{tabular}{ll}
\hline Outcomes & Mortality, invasive infection, NEC, time to full enteral nutrition, time to discharge \\
\hline Notes & Trial included term and preterm infants, subgroup data for preterm infants were provided by authors \\
& Setting: Neonatal Intensive Care Unit at Hospital Universiti Sains, Malaysia \\
\hline
\end{tabular}

\section{Risk of bias}

\begin{tabular}{lll}
\hline Bias & Authors' judgement & Support for judgement \\
\hline $\begin{array}{l}\text { Random sequence genera- } \\
\text { tion (selection bias) }\end{array}$ & Low risk & Randomly permuted blocks \\
\hline $\begin{array}{l}\text { Allocation concealment } \\
\text { (selection bias) }\end{array}$ & Low risk & $\begin{array}{l}\text { Randomisation sequence was generated by a person who was not directly in- } \\
\text { volved in recruitment or care of the infants }\end{array}$ \\
\hline $\begin{array}{l}\text { Blinding (performance } \\
\text { bias and detection bias) } \\
\text { All outcomes }\end{array}$ & Low risk & Investigators and treating staff blinded \\
\hline
\end{tabular}

Incomplete outcome data Low risk Complete follow up assessment

(attrition bias)

All outcomes

Neu 1997

\begin{tabular}{ll}
\hline Methods & Randomised controlled trial \\
\hline Participants & $\begin{array}{l}68 \text { newborn infants (birth weight } 500-1250 \text { grams, gestational age } 24-32 \text { weeks) aged <3 days } \\
\text { Exclusion criteria: congenital anomalies of gastrointestinal tract, NEC, major surgery, breast fed infants, } \\
\text { infants considered nonviable } \\
\text { Duration: } 3 \text { - } 30 \text { days of life }\end{array}$ \\
\hline Interventions & $\begin{array}{l}\text { Treatment: enteral glutamine added to commercial preterm formula feed }(n=35) \\
\text { Control: no added glutamine ( } n=33)\end{array}$ \\
\hline Outcomes & $\begin{array}{l}\text { Mortality, invasive infection, NEC, duration of hospital stay } \\
\text { to } 0.31 \mathrm{~g} / \mathrm{kg} / \text { day by day } 13 . \text { Glutamine supplementation was stopped on day } 30 . \text { All infants received the } \\
\text { same level of parenteral nutrition (without added glutamine) while enteral feeds were being advanced. } \\
\text { Setting: Neonatal Intensive Care Unit, Shands Hospital at University of Florida, USA }\end{array}$ \\
\hline Notes &
\end{tabular}

\section{Risk of bias}

\section{Bias}

Random sequence generation (selection bias)

\section{Authors' judgement Support for judgement}

Low risk Computer generated 
Neu 1997 (Continued)

\begin{tabular}{|c|c|c|}
\hline $\begin{array}{l}\text { Allocation concealment } \\
\text { (selection bias) }\end{array}$ & Low risk & Sealed envelopes \\
\hline $\begin{array}{l}\text { Blinding (performance } \\
\text { bias and detection bias) } \\
\text { All outcomes }\end{array}$ & Low risk & All investigators and caregivers blinded \\
\hline $\begin{array}{l}\text { Incomplete outcome data } \\
\text { (attrition bias) } \\
\text { All outcomes }\end{array}$ & Low risk & $\begin{array}{l}\text { Of the } 68 \text { infants enrolled, } 27 \text { were withdrawn from the study for the follow- } \\
\text { ing reasons: transfer ( } 1 \text { treated and } 1 \text { control), illness or intolerance of enteral } \\
\text { feeding ( } 9 \text { treated and } 16 \text { control). All but the two infants who were transferred } \\
\text { from the study centre were included in the analysis whether they were able to } \\
\text { adhere completely to the feeding protocol or not. }\end{array}$ \\
\hline
\end{tabular}

Pawlik 2012

\begin{tabular}{ll}
\hline Methods & Randomised controlled trial \\
\hline Participants & 106 very low birth weight infants \\
\hline Interventions & Treatment: glutamine/amino acid solution added to usual human milk or formula ( $\mathrm{n}=50)$ \\
\hline Cutcomes & Feeding intolerance, NEC, intestinal perforation, sepsis, mortality \\
\hline Notes & Paper published in Polish with only the abstract and some outcome data available in English. Despite \\
contacting the authors, no further details could be obtained.
\end{tabular}

\section{Risk of bias}

\begin{tabular}{lll}
\hline Bias & Authors' judgement & Support for judgement \\
\hline $\begin{array}{l}\text { Random sequence genera- } \\
\text { tion (selection bias) }\end{array}$ & Unclear risk & $\begin{array}{l}\text { Methological details were not reported in the abstract. This table will be up- } \\
\text { dated if further details are made available to us by the authors. }\end{array}$ \\
\hline $\begin{array}{l}\text { Allocation concealment } \\
\text { (selection bias) }\end{array}$ & Unclear risk & Methological details were not reported in the abstract. \\
\hline $\begin{array}{l}\text { Blinding (performance } \\
\text { bias and detection bias) } \\
\text { All outcomes }\end{array}$ & Unclear risk & Methological details were not reported in the abstract. \\
\hline $\begin{array}{l}\text { Incomplete outcome data } \\
\text { (attrition bias) } \\
\text { All outcomes }\end{array}$ & Unclear risk & Methological details were not reported in the abstract. \\
\hline
\end{tabular}

\section{Poindexter 2004}

\begin{tabular}{ll}
\hline Methods & Randomised controlled trial \\
\hline Participants & 1433 extremely low birth weight infants enrolled within 72 hours of birth \\
& $\begin{array}{l}\text { Exclusion criteria: major congenital anomalies, congenital non-bacterial infection, terminal illness, de- } \\
\text { cision made not to provide full intensive care and support }\end{array}$ \\
\hline
\end{tabular}


Poindexter 2004 (Continued)

Duration: birth to 120 days

Interventions Treatment: $20 \%$ glutamine added to standard parenteral nutrition solution $(n=721)$

Control: no added glutamine $(n=712)$

Outcomes

Primary: Composite outcome of death or late-onset sepsis

Secondary: Number of episodes of late-onset invasive infection, rate of NEC, duration of mechanical ventilation, length of hospital stay, measures of feeding tolerance and intolerance, duration of parenteral nutrition, growth parameters

Notes Setting: 15 neonatal care centres in the USA (1999-2001)

\section{Risk of bias}

\begin{tabular}{lll}
\hline Bias & Authors' judgement & Support for judgement \\
\hline $\begin{array}{l}\text { Random sequence genera- } \\
\text { tion (selection bias) }\end{array}$ & Low risk & Random sequence generated by data coordination centre \\
\hline $\begin{array}{l}\text { Allocation concealment } \\
\text { (selection bias) }\end{array}$ & Low risk & Hospital pharmacists allocated infants to control or glutamine group \\
\hline $\begin{array}{l}\text { Blinding (performance } \\
\text { bias and detection bias) } \\
\text { All outcomes }\end{array}$ & Low risk & $\begin{array}{l}\text { The caregivers were not aware whether participating infants received gluta- } \\
\text { mine-supplemented or non-supplemented parenteral nutrition }\end{array}$ \\
\hline $\begin{array}{l}\text { Incomplete outcome data } \\
\text { (attrition bias) } \\
\text { All outcomes }\end{array}$ & Low risk & One baby (glutamine) lost to follow-up \\
\hline
\end{tabular}

Sevastiadou 2011

\begin{tabular}{|c|c|}
\hline Methods & Randomised controlled trial \\
\hline \multirow[t]{3}{*}{ Participants } & 101 formula fed preterm infants, birth weight $<2 \mathrm{~kg}$, gestational age $<34$ weeks \\
\hline & $\begin{array}{l}\text { Exclusion criteria: congenital or chromosomal anomalies, severe hypotension, severe perinatal dis- } \\
\text { tress, abdominal distention, signs of early NEC }\end{array}$ \\
\hline & Duration: 3 - 30 days \\
\hline \multirow[t]{2}{*}{ Interventions } & $\begin{array}{l}\text { Treatment: } 10 \% \text { glutamine solution, administered enterally } 3 x \text { daily }(n=51) \text {, dosage adjusted to actual } \\
\text { weight }(0.3 \mathrm{~g} / \mathrm{kg} / \text { day })\end{array}$ \\
\hline & Control: isocaloric "caloreen" (glucose polymer) supplementation $(n=50)$ \\
\hline Outcomes & Measures of intestinal permeability \\
\hline \multirow[t]{2}{*}{ Notes } & Unpublished invasive infection and NEC data provided by authors \\
\hline & Setting: Neonatal Intensive Care Unit at Alexandra Regional General Hospital, Greece (2007-8) \\
\hline
\end{tabular}

\section{Risk of bias}

\section{Bias}

\section{Authors' judgement Support for judgement}


Sevastiadou 2011 (Continued)

\begin{tabular}{|c|c|c|}
\hline $\begin{array}{l}\text { Random sequence genera- } \\
\text { tion (selection bias) }\end{array}$ & Unclear risk & Not reported \\
\hline $\begin{array}{l}\text { Allocation concealment } \\
\text { (selection bias) }\end{array}$ & Unclear risk & Not reported \\
\hline $\begin{array}{l}\text { Blinding (performance } \\
\text { bias and detection bias) } \\
\text { All outcomes }\end{array}$ & Low risk & Nursing staff blinded \\
\hline $\begin{array}{l}\text { Incomplete outcome data } \\
\text { (attrition bias) } \\
\text { All outcomes }\end{array}$ & Low risk & $\begin{array}{l}25 \text { participants exited the study after randomisation (16 in control group: } 4 \\
\text { died, in } 12 \text { urine collection failed; } 9 \text { in glutamine group: } 3 \text { died, in } 6 \text { urine col- } \\
\text { lection failed) }\end{array}$ \\
\hline
\end{tabular}

Thompson 2003

\begin{tabular}{ll}
\hline Methods & Randomised controlled trial \\
\hline Participants & $\begin{array}{l}35 \text { very low birth weight infants with a need for mechanical ventilation or more than 40\% oxygen en- } \\
\text { rolled on day one of postnatal life } \\
\text { Exclusion criteria: renal or hepatic dysfunction, suspected congenital anomalies of the gastrointestinal } \\
\text { tract, lethal congenital anomalies }\end{array}$ \\
\hline Interventions & $\begin{array}{l}\text { Treatment: } 2.5 \% \text { glutamine solution given along with standard parenteral nutrition ( } \mathrm{n}=17 \text { ), increased } \\
\text { to maximum of } 3 \mathrm{~g} / \mathrm{kg} / \mathrm{day}\end{array}$ \\
& Control: sterile water with no added glutamine (n = 18) \\
\hline Outcomes & $\begin{array}{l}\text { Time to full enteral feeds, number of episodes of sepsis, rate of weight gain, measures of feeding toler- } \\
\text { ance and intolerance, rate of NEC }\end{array}$ \\
\hline Notes & $\begin{array}{l}\text { Infants in the intervention group received a solution of 2.5\% L-glutamine given as a separate but simul- } \\
\text { taneous infusion with the remainder of the parenteral nutrition. The glutamine comprised approxi- } \\
\text { mately } 16 \% \text { of total amino acids. Control infants received an infusion of water indistinguishable in ap- } \\
\text { pearance to the glutamine solution. Parenteral nutrition and glutamine supplementation was discon- } \\
\text { tinued when enteral feeding exceeded 80\% of total energy requirements } \\
\text { Setting: Regional Neonatal Unit in Royal Maternity Hospital, Belfast, UK (late 1990s) }\end{array}$ \\
\hline
\end{tabular}

\section{Risk of bias}

\begin{tabular}{lll}
\hline Bias & Authors' judgement & Support for judgement \\
\hline $\begin{array}{l}\text { Random sequence genera- } \\
\text { tion (selection bias) }\end{array}$ & Low risk & Four-block randomisation sequence generated off-site \\
\hline $\begin{array}{l}\text { Allocation concealment } \\
\text { (selection bias) }\end{array}$ & Low risk & $\begin{array}{l}\text { Hospital pharmacists randomly allocated one solution to be control and one } \\
\text { to be glutamine supplemented }\end{array}$ \\
\hline $\begin{array}{l}\text { Blinding (performance } \\
\text { bias and detection bias) } \\
\text { All outcomes }\end{array}$ & Low risk & Main researcher, medical and nursing staff blinded \\
\hline $\begin{array}{l}\text { Incomplete outcome data } \\
\text { (attrition bias) }\end{array}$ & Low risk & 5 infants in the glutamine group and 2 in the control group died
\end{tabular}


Thompson 2003 (Continued)

All outcomes

van den Berg 2005

\begin{tabular}{ll}
\hline Methods & Randomised controlled trial \\
\hline
\end{tabular}

Participants 107 very low birth weight or very preterm infants

Exclusion criteria: major congenital or chromosomal anomalies, death or transfer to another hospital within $48 \mathrm{hrs}$ of birth, admission from extra regional hospital

Duration: 3 - 30 days of life

Interventions

Treatment: enteral glutamine supplementation to breast milk or formula (up to $0.3 \mathrm{~g} / \mathrm{kg} / \mathrm{day} ; \mathrm{n}=54$ ), after two weeks the dosage was adjusted to actual weight of the infants

Control: placebo (alanine) in breast milk or formula $(n=53)$

Outcomes Primary: time to full enteral feeding

Secondary: other variables of feeding tolerance, NEC, days of no enteral feeding, incidence of serious infection, growth, need for mechanical ventilation, age at discharge, death

Neurodevelopmental outcomes

Cognitive development, cerebral palsy, blindness and hearing loss were assessed at 24 months corrected age. Out of the 107 infants initially randomised, 88 were eligible for 2 year follow-up. Data were available for 72 infants (glutamine: $n=40$, control: $n=32$ ).

On follow-up at age 7 to 8 years, 68 children were assessed. Four of these children had serious motor ( $\mathrm{n}$ $=2$ ), hearing $(n=1)$, or visual $(n=1)$ difficulties which hindered them from participation. It is not known if these children received glutamine or placebo. Parents and teachers completed questionnaires addressing any behavioural problems at home or in school, respectively. The following cognitive and motor measures were also assessed: the Wechsler Intelligence Scale for Children to assess intellectual development, the Movement Assessment Battery for Children to assess motor development, and an adapted version of the Attention Network Test to assess orienting, executive, and alerting attention.

Notes

After randomisation 5 infants were excluded due to clinical complications, therefore glutamine group $\mathrm{n}$ $=52$, control $\mathrm{n}=50$

Setting: Level III Neonatal Intensive Care Unit of VU University Medical Centre, Amsterdam, The Netherlands

\section{Risk of bias}

\begin{tabular}{lll}
\hline Bias & Authors' judgement & Support for judgement \\
\hline $\begin{array}{l}\text { Random sequence genera- } \\
\text { tion (selection bias) }\end{array}$ & Low risk & Computer generated randomisation table based on blocks of four \\
\hline $\begin{array}{l}\text { Allocation concealment } \\
\text { (selection bias) }\end{array}$ & Low risk & Sealed code batch numbers \\
\hline $\begin{array}{l}\text { Blinding (performance } \\
\text { bias and detection bias) } \\
\text { All outcomes }\end{array}$ & Low risk & $\begin{array}{l}\text { Investigators, parents, medical and nursing staff were not aware which solu- } \\
\text { tion infants received }\end{array}$ \\
\hline
\end{tabular}

Incomplete outcome data High risk

17 (glutamine) and 11 (control) infants were lost to follow-up (attrition bias) 
van den Berg 2005 (Continued)

All outcomes

Vaughn 2003

\begin{tabular}{|c|c|}
\hline Methods & Randomised controlled trial \\
\hline \multirow[t]{3}{*}{ Participants } & 649 newborn infants with birth weight 500 - 1250 grams \\
\hline & $\begin{array}{l}\text { Exclusion criteria: major chromosomal or congenital anomalies, high probability of death within } 3 \\
\text { days, diagnosed with NEC within } 7 \text { days after birth }\end{array}$ \\
\hline & Duration: between 7 days and 36 weeks \\
\hline \multirow[t]{2}{*}{ Interventions } & $\begin{array}{l}\text { Treatment: } 5 \mathrm{ml} / \mathrm{kg} \text { of } 3 \% \text { glutamine solution given enterally } 12 \text {-hourly for the first } 28 \text { days }(n=314) \text {; } \\
\text { dosage not adjusted to weight }\end{array}$ \\
\hline & Control: sterile water with no added glutamine $(n=335)$ \\
\hline \multirow[t]{2}{*}{ Outcomes } & Primary: Number of infants with positive blood cultures from 7 days to 36 weeks postmenstrual age. \\
\hline & $\begin{array}{l}\text { Secondary: Number of episodes of sepsis, measures of growth, rates of other neonatal morbidities in- } \\
\text { cluding NEC, and length of hospital stay }\end{array}$ \\
\hline \multirow[t]{2}{*}{ Notes } & Glutamine/control solution given at the same time but separate from milk feeds \\
\hline & Setting: 20 neonatal care centres in the USA (late 1990s) \\
\hline
\end{tabular}

\section{Risk of bias}

\begin{tabular}{lll}
\hline Bias & Authors' judgement & Support for judgement \\
\hline $\begin{array}{l}\text { Random sequence genera- } \\
\text { tion (selection bias) }\end{array}$ & Low risk & Blocks of 10 for each of 3 birth weight strata \\
\hline $\begin{array}{l}\text { Allocation concealment } \\
\text { (selection bias) }\end{array}$ & Low risk & Sequentially numbered opaque envelopes \\
\hline $\begin{array}{l}\text { Blinding (performance } \\
\text { bias and detection bias) }\end{array}$ & Low risk & Caregivers were not aware which solution infants received \\
All outcomes & \\
\hline $\begin{array}{l}\text { Incomplete outcome data } \\
\text { (attrition bias) }\end{array}$ & Low risk & $\begin{array}{l}\text { Although 105 (56 treated and 49 control) infants left the study before complet- } \\
\text { ing a full course of treatment due to death (39), transfer to another hospital } \\
\text { (24), NEC (24), meeting exclusion criteria after enrolment (12), discharge home } \\
\text { (2) and parental request (4), outcome analyses in the published report and in } \\
\text { this review are intention-to-treat. }\end{array}$ \\
\hline
\end{tabular}

Wang 2010

\begin{tabular}{ll}
\hline Methods $\quad$ Randomised controlled trial \\
\hline Participants
\end{tabular}

Participants

28 very low birth weight infants receiving parenteral nutrition for at least 7 days 
Wang 2010 (Continued)

Exclusion criteria: pre-existing renal or hepatic dysfunction, congenital errors of metabolism, major chromosomal disease, cytomegalovirus infection, viral hepatitis, congenital or acquired immune deficiency

\begin{tabular}{ll}
\hline Interventions & Intervention: parenteral glutamine $0.3 \mathrm{~g} / \mathrm{kg} /$ day added to parenteral nutrition \\
& Control: no glutamine ( $6 \%$ amino acid) \\
\hline Outcomes & $\begin{array}{l}\text { Time to full enteral nutrition, weight gain, head circumference, length of hospitalisation, days on venti- } \\
\text { lator }\end{array}$ \\
\hline Notes & $\begin{array}{l}\text { Data on invasive infection, NEC, time to full enteral nutrition, and duration of hospital stay were re- } \\
\text { quested from the authors (not available May 2014) } \\
\text { Setting: two neonatal care centres in China (mid-late } 2000 \mathrm{~s})\end{array}$
\end{tabular}

\section{Risk of bias}

\begin{tabular}{lll}
\hline Bias & Authors' judgement & Support for judgement \\
\hline $\begin{array}{l}\text { Random sequence genera- } \\
\text { tion (selection bias) }\end{array}$ & Low risk & Unique randomisation code \\
\hline $\begin{array}{l}\text { Allocation concealment } \\
\text { (selection bias) }\end{array}$ & Low risk & Sequentially numbered, sealed, opaque envelopes \\
\hline $\begin{array}{l}\text { Blinding (performance } \\
\text { bias and detection bias) } \\
\text { All outcomes }\end{array}$ & Low risk & Investigators, parents, physicians, nurses blinded \\
\hline $\begin{array}{l}\text { Incomplete outcome data } \\
\text { (attrition bias) } \\
\begin{array}{l}\text { All outcomes } \\
\hline\end{array}\end{array}$ & Low risk & $\mathrm{n}=4$ from control group and $\mathrm{n}=2$ from glutamine group were withdrawn \\
\hline
\end{tabular}

$\mathrm{NEC}=$ necrotising enterocolitis

Characteristics of excluded studies [ordered by study ID]

\begin{tabular}{ll}
\hline Study & Reason for exclusion \\
\hline Barbosa 1999 & No preterm infants \\
\hline Li 2007 & Not a randomised controlled trial \\
\hline Strujis 2013 & Term infants, average gestational age 37 weeks \\
\hline
\end{tabular}

Characteristics of ongoing studies [ordered by study ID]

\section{NCT00213668}

\begin{tabular}{ll}
\hline Trial name or title & Effect of Glutamine on Gastric Emptying and Length of Parenteral Nutrition in Premature Neonates \\
\hline Methods & Randomised controlled trial \\
\hline
\end{tabular}


NCT00213668 (Continued)

Participants Premature neonates

\begin{tabular}{ll}
\hline Interventions & Dietary supplement: glutamine (dipeptiven) \\
\hline Outcomes & $\begin{array}{l}\text { Primary outcome measure: gastric emptying } \\
\text { Secondary outcome measures: intestinal transit time, age at total enteral nutrition, age at the end } \\
\text { of hospitalisation, variation of cholecystokinin and gastrin postprandial concentration }\end{array}$
\end{tabular}

Starting date April 2002

Contact information

Contact: Anne Mercier, MD

02-32-88-80-97 ext 02-33-89-42-62

anne.mercier@ch-avranches-granville.fr

\section{Notes}

\section{NCT01263041}

\begin{tabular}{ll}
\hline Trial name or title & Effect of L-arginine and Glutamine on Preterm (preterm) \\
\hline Methods & Randomised controlled trial \\
\hline Participants & Preterm infants \\
\hline Interventions & $\begin{array}{l}\text { Drug: enteral glutamine } \\
\text { Drug: l-arginine } \\
\text { Other: placebo }\end{array}$ \\
\hline Outcomes & $\begin{array}{l}\text { Primary outcome measures: necrotising enterocolitis incidence, sepsis incidence, severity and out- } \\
\text { come } \\
\text { Secondary outcome measures: incidence, severity and outcome of respiratory distress syndrome, } \\
\text { pulmonary hypertension, intracranial haemorrhage }\end{array}$ \\
\hline Starting date & December 2010 \\
\hline Contact information & Prof. Hesham Awad \\
& Ain Shams University
\end{tabular}

Notes

\section{DATA AND ANALYSES}


Comparison 1. Glutamine supplementation versus no supplementation

\begin{tabular}{|c|c|c|c|c|}
\hline Outcome or subgroup title & No. of studies & $\begin{array}{l}\text { No. of partici- } \\
\text { pants }\end{array}$ & Statistical method & Effect size \\
\hline $\begin{array}{l}1 \text { Death prior to hospital dis- } \\
\text { charge }\end{array}$ & 12 & 2877 & Risk Ratio (M-H, Fixed, 95\% Cl) & $0.97[0.80,1.17]$ \\
\hline 1.1 Enteral supplementation & 6 & 1095 & Risk Ratio (M-H, Fixed, 95\% Cl) & $0.93[0.58,1.49]$ \\
\hline $\begin{array}{l}\text { 1.2 Parenteral supplementa- } \\
\text { tion }\end{array}$ & 6 & 1782 & Risk Ratio (M-H, Fixed, 95\% Cl) & $0.97[0.79,1.20]$ \\
\hline $\begin{array}{l}2 \text { Neurodevelopmental impair- } \\
\text { ment }\end{array}$ & 1 & 72 & Risk Ratio (M-H, Fixed, 95\% Cl) & $1.07[0.59,1.92]$ \\
\hline 2.1 Enteral supplementation & 1 & 72 & Risk Ratio (M-H, Fixed, 95\% Cl) & $1.07[0.59,1.92]$ \\
\hline $\begin{array}{l}\text { 2.2 Parenteral supplementa- } \\
\text { tion }\end{array}$ & 0 & 0 & Risk Ratio (M-H, Fixed, 95\% Cl) & $0.0[0.0,0.0]$ \\
\hline 3 Invasive infection & 11 & 2815 & Risk Ratio (M-H, Fixed, 95\% Cl) & $0.94[0.86,1.04]$ \\
\hline 3.1 Enteral supplementation & 6 & 1095 & Risk Ratio (M-H, Fixed, 95\% Cl) & $0.76[0.64,0.89]$ \\
\hline $\begin{array}{l}\text { 3.2 Parenteral supplementa- } \\
\text { tion }\end{array}$ & 5 & 1720 & Risk Ratio (M-H, Fixed, 95\% Cl) & $1.06[0.94,1.20]$ \\
\hline 4 Necrotising enterocolitis & 11 & 2849 & Risk Ratio (M-H, Fixed, 95\% Cl) & $0.83[0.66,1.06]$ \\
\hline 4.1 Enteral supplementation & 7 & 1172 & Risk Ratio (M-H, Fixed, 95\% Cl) & $0.73[0.49,1.08]$ \\
\hline $\begin{array}{l}4.2 \text { Parenteral supplementa- } \\
\text { tion }\end{array}$ & 4 & 1677 & Risk Ratio (M-H, Fixed, 95\% Cl) & $0.90[0.67,1.22]$ \\
\hline 5 Rate of weight gain (g/day) & 3 & 100 & Mean Difference (IV, Fixed, 95\% CI) & $0.59[-1.42,2.59]$ \\
\hline 5.1 Enteral supplementation & 0 & 0 & Mean Difference (IV, Fixed, 95\% CI) & $0.0[0.0,0.0]$ \\
\hline $\begin{array}{l}5.2 \text { Parenteral supplementa- } \\
\text { tion }\end{array}$ & 3 & 100 & Mean Difference (IV, Fixed, 95\% CI) & $0.59[-1.42,2.59]$ \\
\hline $\begin{array}{l}6 \text { Time to full enteral nutrition } \\
\text { (days) }\end{array}$ & 7 & 1594 & Mean Difference (IV, Fixed, 95\% CI) & $-1.68[-2.88,-0.48]$ \\
\hline 6.1 Enteral supplementation & 2 & 171 & Mean Difference (IV, Fixed, 95\% CI) & $-2.63[-4.99,-0.27]$ \\
\hline $\begin{array}{l}6.2 \text { Parenteral supplementa- } \\
\text { tion }\end{array}$ & 5 & 1423 & Mean Difference (IV, Fixed, 95\% CI) & $-1.35[-2.74,0.05]$ \\
\hline $\begin{array}{l}7 \text { Duration of hospital stay } \\
\text { (days) }\end{array}$ & 8 & 2174 & $\begin{array}{l}\text { Mean Difference (IV, Random, 95\% } \\
\text { CI) }\end{array}$ & $-0.85[-3.39,1.70]$ \\
\hline 7.1 Enteral supplementation & 3 & 753 & $\begin{array}{l}\text { Mean Difference (IV, Random, 95\% } \\
\text { CI) }\end{array}$ & $-1.32[-5.55,2.92]$ \\
\hline $\begin{array}{l}\text { 7.2 Parenteral supplementa- } \\
\text { tion }\end{array}$ & 5 & 1421 & $\begin{array}{l}\text { Mean Difference (IV, Random, 95\% } \\
\mathrm{CI} \text { ) }\end{array}$ & $-0.58[-3.77,2.61]$ \\
\hline
\end{tabular}


Analysis 1.1. Comparison 1 Glutamine supplementation versus no supplementation, Outcome 1 Death prior to hospital discharge.

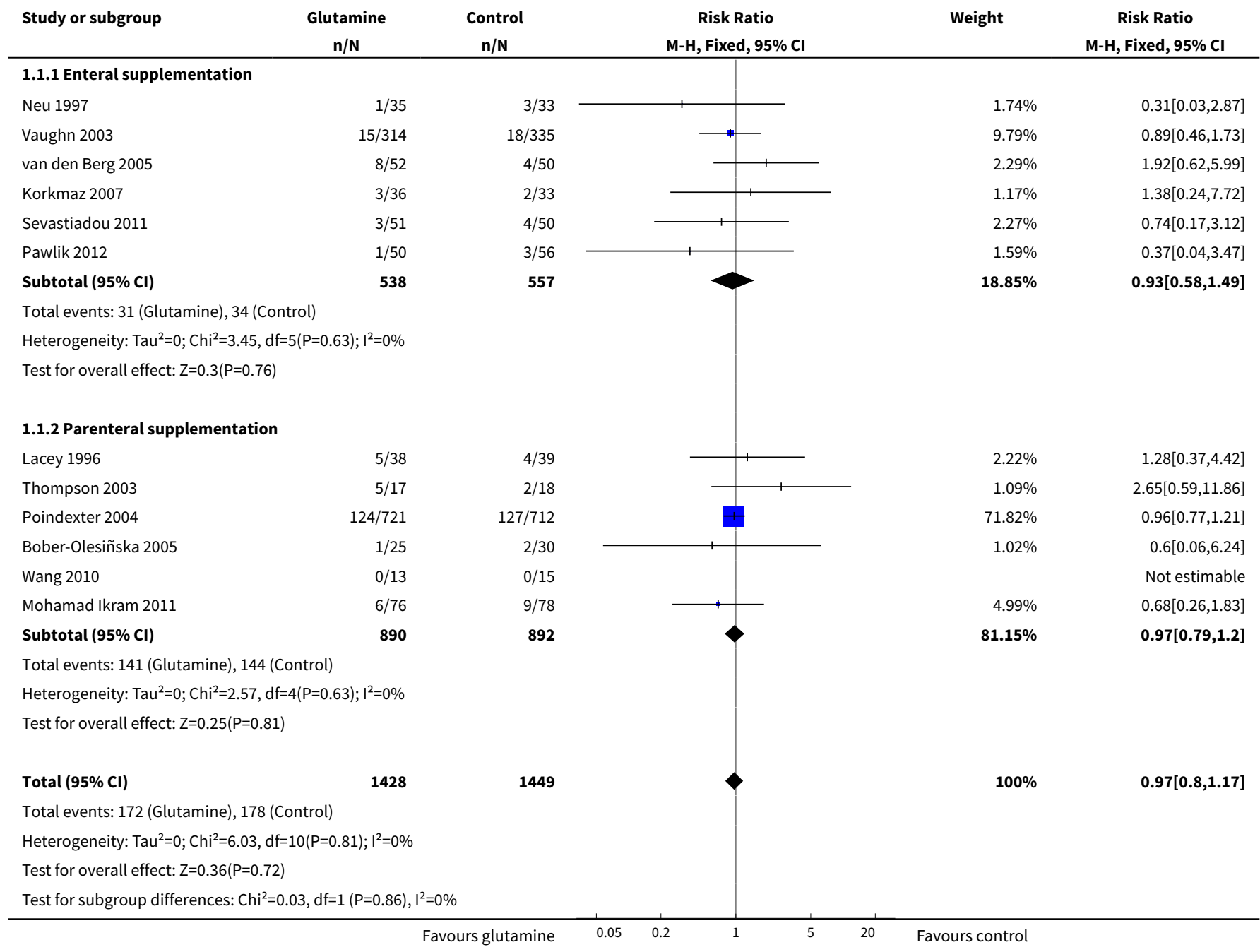

\section{Analysis 1.2. Comparison 1 Glutamine supplementation versus no supplementation, Outcome 2 Neurodevelopmental impairment.}

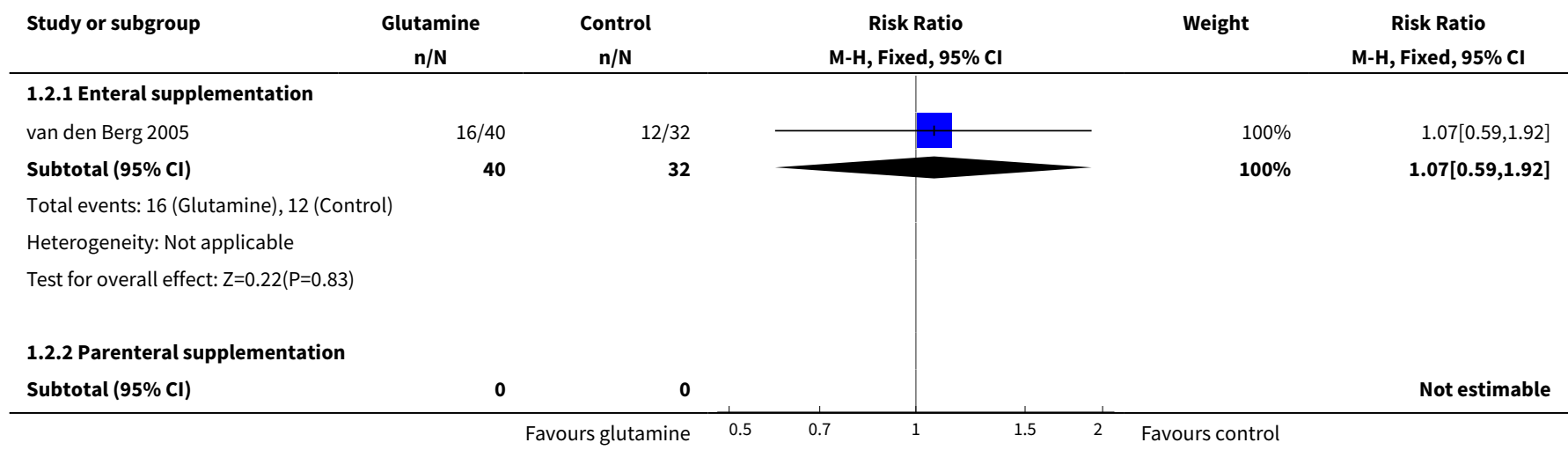




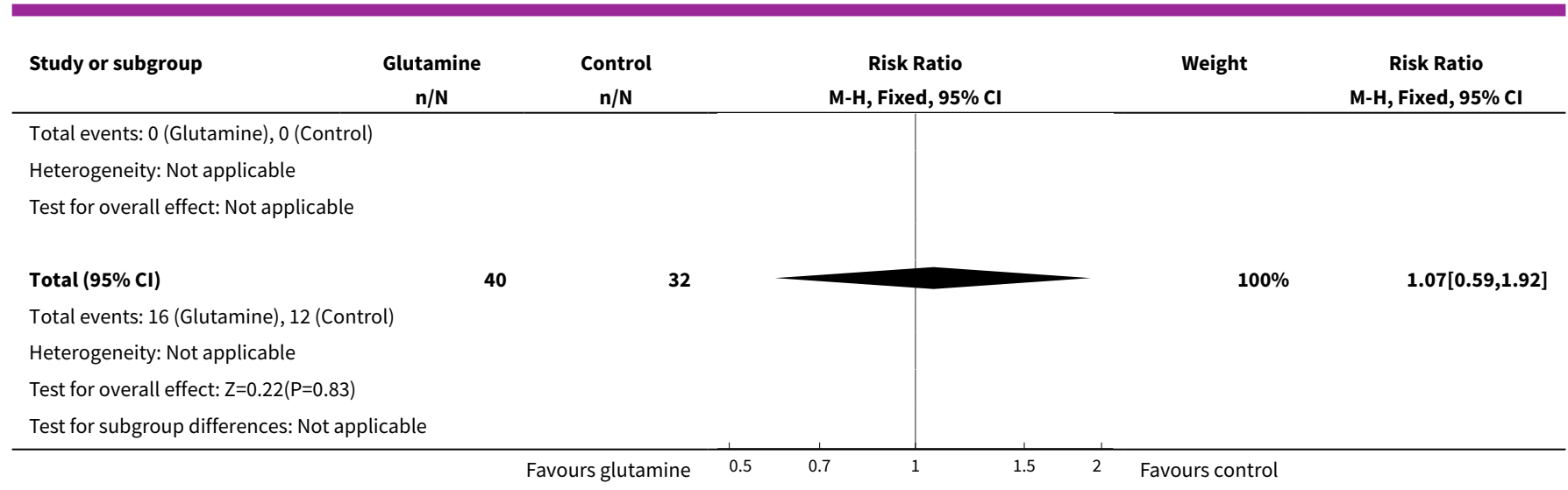

\section{Analysis 1.3. Comparison 1 Glutamine supplementation versus no supplementation, Outcome 3 Invasive infection.}

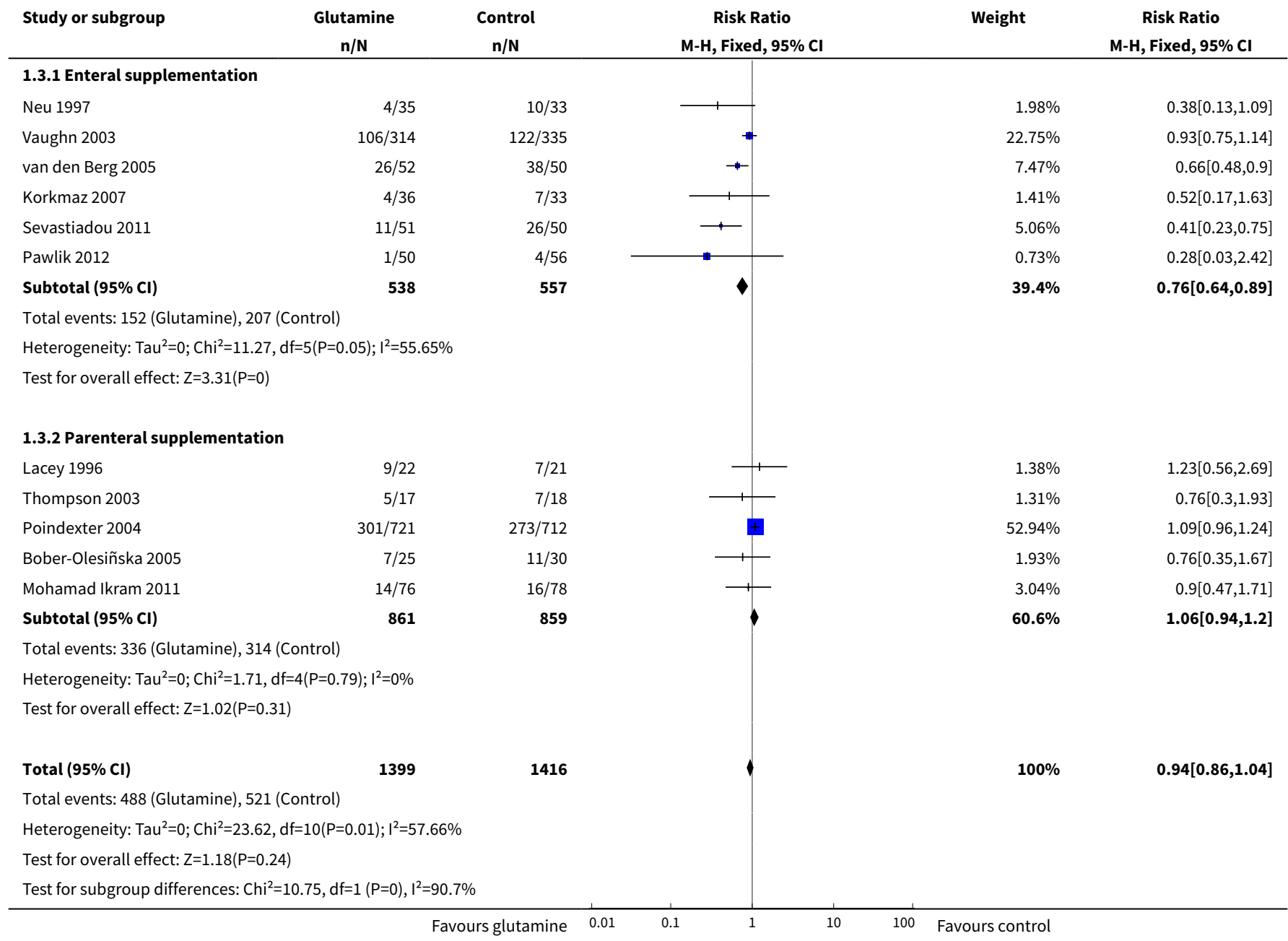


Analysis 1.4. Comparison 1 Glutamine supplementation versus no supplementation, Outcome 4 Necrotising enterocolitis.

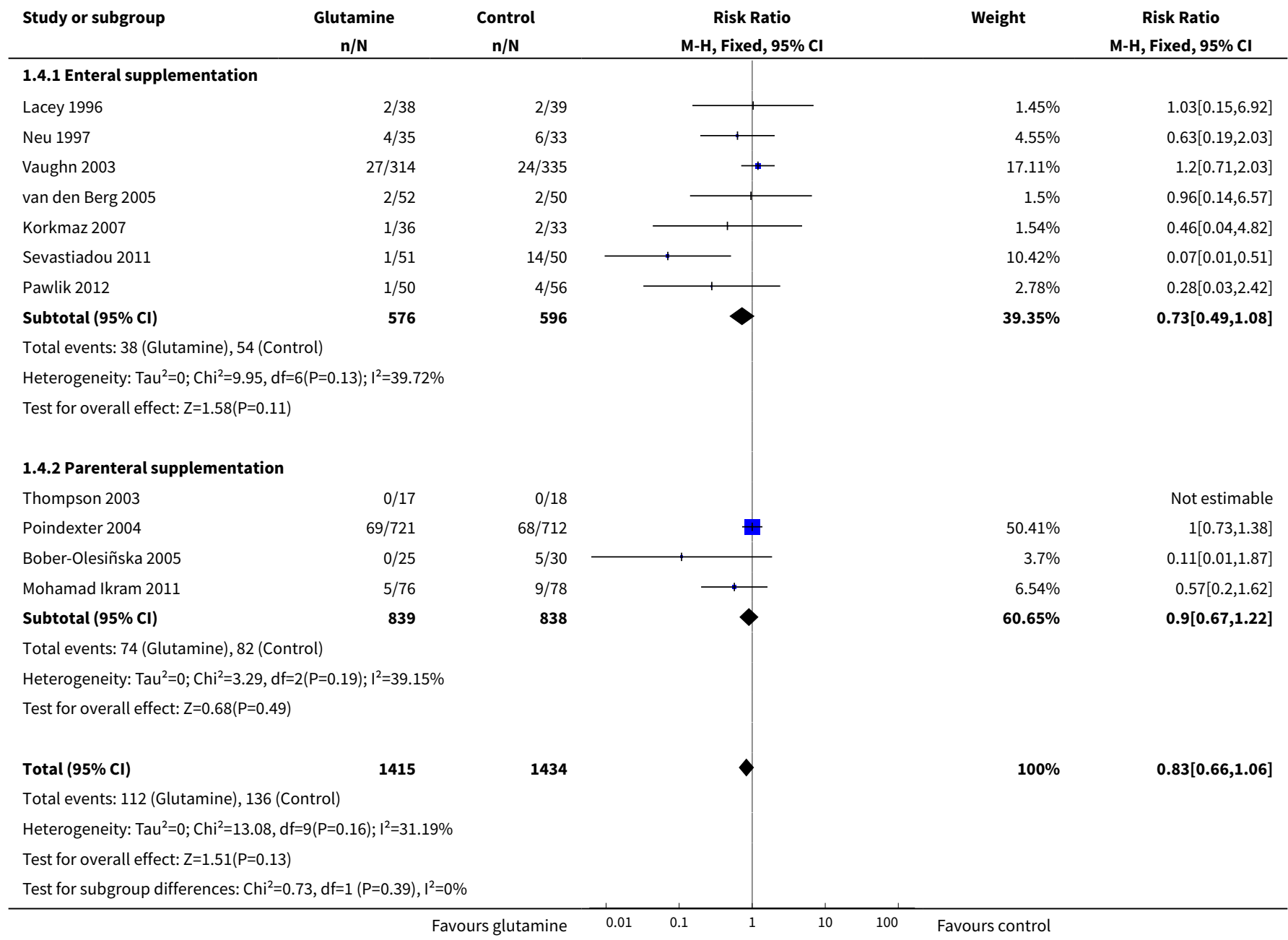

\section{Analysis 1.5. Comparison $1 \mathrm{Glutamine}$ supplementation versus no supplementation, Outcome 5 Rate of weight gain (g/day).}

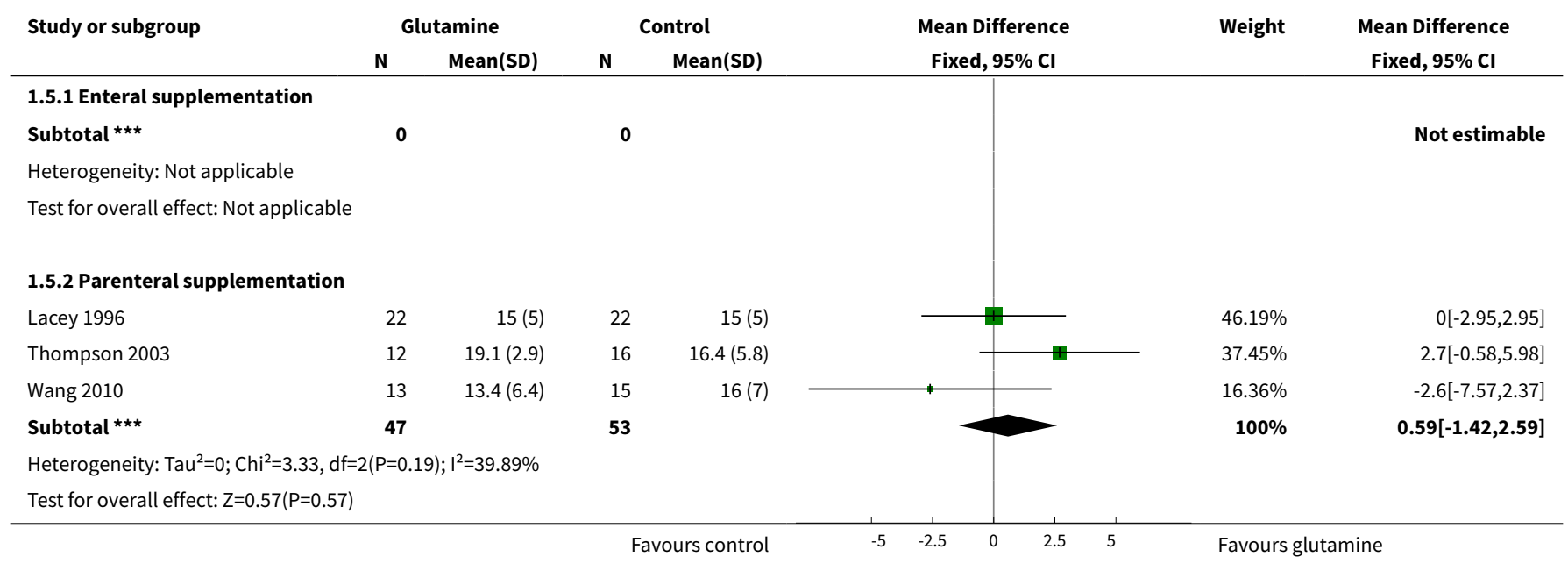




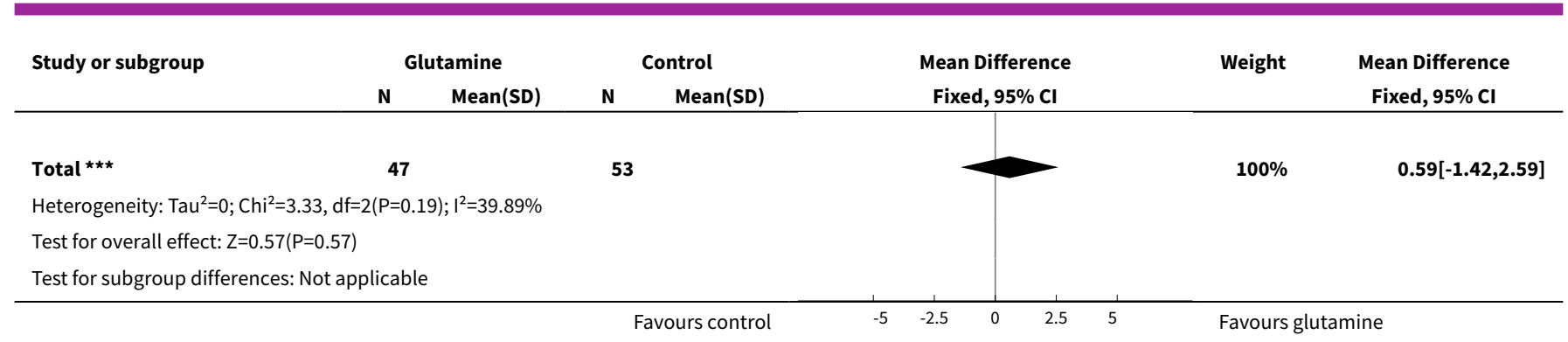

Analysis 1.6. Comparison 1 Glutamine supplementation versus no supplementation, Outcome 6 Time to full enteral nutrition (days).

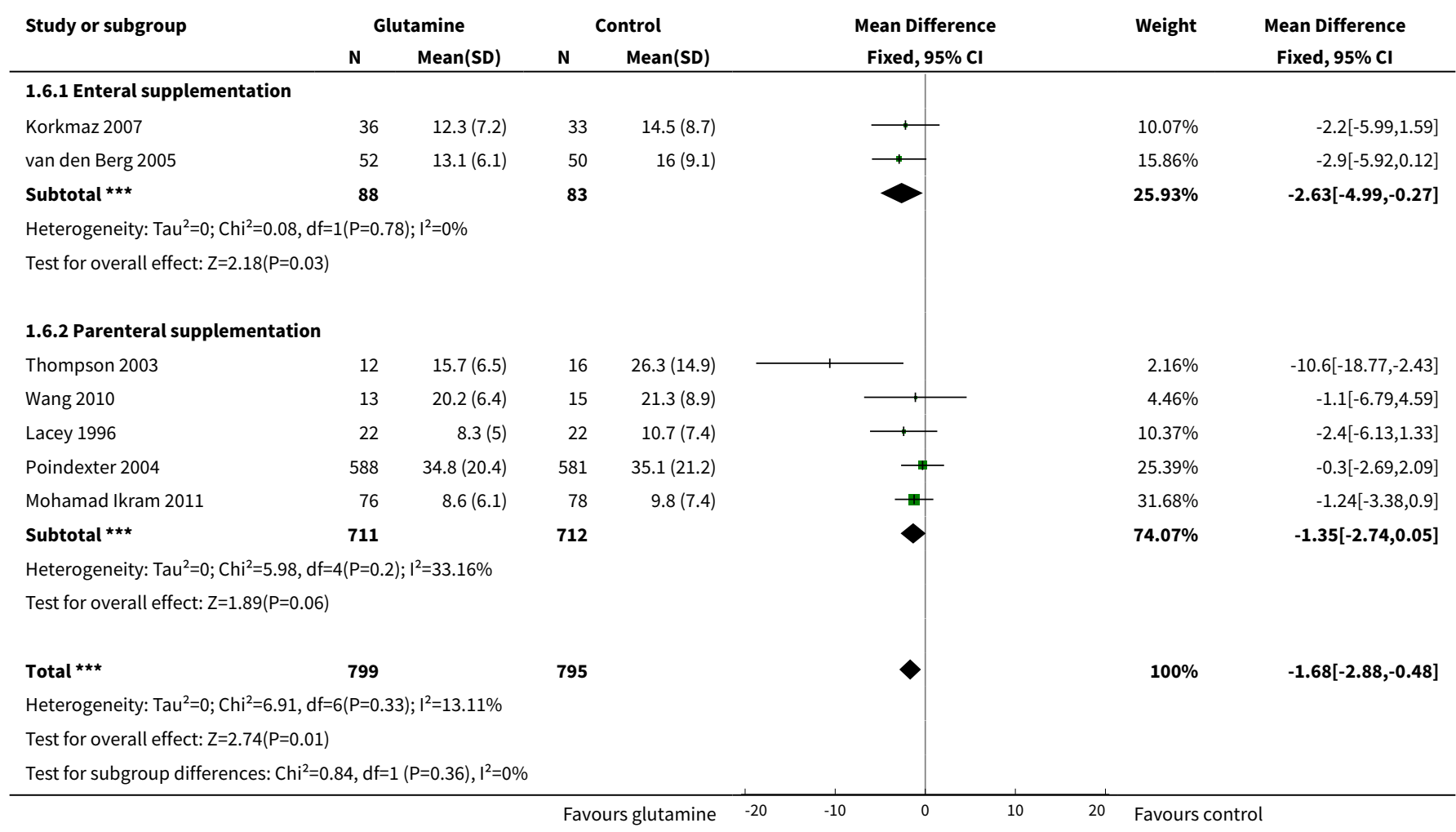

Analysis 1.7. Comparison 1 Glutamine supplementation versus no supplementation, Outcome 7 Duration of hospital stay (days).

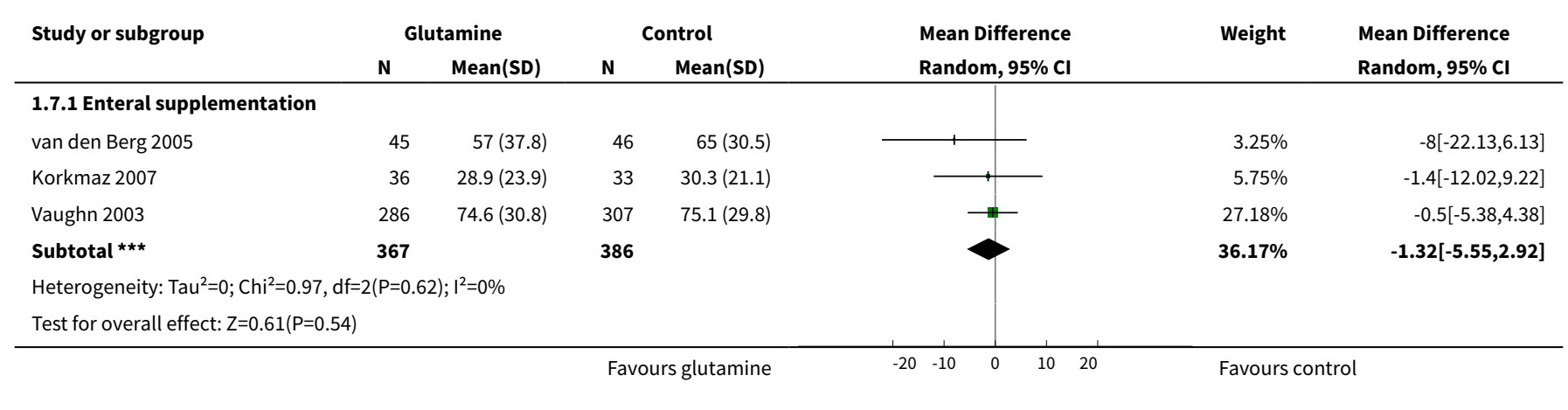




\begin{tabular}{|c|c|c|c|c|c|c|c|}
\hline \multirow[t]{2}{*}{ Study or subgroup } & \multicolumn{2}{|c|}{ Glutamine } & \multicolumn{2}{|c|}{ Control } & \multirow{2}{*}{$\begin{array}{l}\text { Mean Difference } \\
\text { Random, } 95 \% \mathrm{Cl}\end{array}$} & \multirow[t]{2}{*}{ Weight } & \multirow{2}{*}{$\begin{array}{l}\text { Mean Difference } \\
\text { Random, } 95 \% \mathrm{Cl}\end{array}$} \\
\hline & $\mathbf{N}$ & $\operatorname{Mean}(S D)$ & $\mathbf{N}$ & Mean(SD) & & & \\
\hline \multicolumn{8}{|c|}{ 1.7.2 Parenteral supplementation } \\
\hline Thompson 2003 & 12 & $92.6(47.1)$ & 16 & $85.4(33.2)$ & & $0.67 \%$ & $7.2[-24.02,38.42]$ \\
\hline Lacey 1996 & 22 & $88(21)$ & 22 & $92(25)$ & 1 & $3.48 \%$ & $-4[-17.64,9.64]$ \\
\hline Wang 2010 & 13 & $48.7(11.4)$ & 15 & $48.3(13.8)$ & - & $7.44 \%$ & $0.4[-8.94,9.74]$ \\
\hline Poindexter 2004 & 597 & $99.9(48.7)$ & 585 & $98.1(43.7)$ & 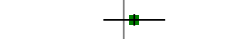 & $23.32 \%$ & $1.8[-3.47,7.07]$ \\
\hline Mohamad Ikram 2011 & 70 & $13.9(12.5)$ & 69 & $16.4(15.8)$ & 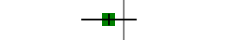 & $28.93 \%$ & $-2.52[-7.25,2.21]$ \\
\hline 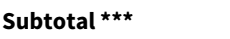 & 714 & & 707 & & & $63.83 \%$ & $-0.58[-3.77,2.61]$ \\
\hline \multicolumn{8}{|c|}{ Heterogeneity: $\mathrm{Tau}^{2}=0 ; \mathrm{Chi}^{2}=1.95, \mathrm{df}=4(\mathrm{P}=0.74) ; \mathrm{I}^{2}=0 \%$} \\
\hline \multicolumn{8}{|c|}{ Test for overall effect: $Z=0.36(P=0.72)$} \\
\hline 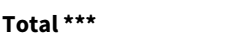 & 1081 & & 1093 & & & $100 \%$ & $-0.85[-3.39,1.7]$ \\
\hline \multicolumn{8}{|c|}{ Heterogeneity: $\mathrm{Tau}^{2}=0 ; \mathrm{Chi}^{2}=2.99, \mathrm{df}=7(\mathrm{P}=0.89) ; \mathrm{I}^{2}=0 \%$} \\
\hline \multicolumn{8}{|c|}{ Test for overall effect: $\mathrm{Z}=0.65(\mathrm{P}=0.51)$} \\
\hline \multicolumn{8}{|c|}{ Test for subgroup differences: $\mathrm{Chi}^{2}=0.07, \mathrm{df}=1(\mathrm{P}=0.79), \mathrm{I}^{2}=0 \%$} \\
\hline & & & Favo & glutamine & $-20-10$ & Favours c & \\
\hline
\end{tabular}

\section{Comparison 2. Trials in low- and middle-income countries}

\begin{tabular}{|c|c|c|c|c|}
\hline Outcome or subgroup title & No. of studies & $\begin{array}{l}\text { No. of partici- } \\
\text { pants }\end{array}$ & Statistical method & Effect size \\
\hline $\begin{array}{l}1 \text { Death prior to hospital dis- } \\
\text { charge }\end{array}$ & 3 & 251 & Risk Ratio (M-H, Fixed, 95\% Cl) & $0.82[0.35,1.90]$ \\
\hline 2 Invasive infection & 2 & 223 & Risk Ratio (M-H, Fixed, 95\% Cl) & $0.78[0.45,1.36]$ \\
\hline 3 Necrotising enterocolitis & 2 & 223 & Risk Ratio (M-H, Fixed, 95\% Cl) & $0.55[0.21,1.43]$ \\
\hline 4 Rate of weight gain (g/day) & 1 & 28 & Mean Difference (IV, Fixed, 95\% CI) & $-2.60[-7.57,2.37]$ \\
\hline $\begin{array}{l}5 \text { Time to full enteral nutrition } \\
\text { (days) }\end{array}$ & 3 & 251 & Mean Difference (IV, Fixed, 95\% CI) & $-1.44[-3.20,0.33]$ \\
\hline $\begin{array}{l}6 \text { Duration of hospital stay } \\
\text { (days) }\end{array}$ & 3 & 236 & Mean Difference (IV, Fixed, 95\% CI) & $-1.85[-5.77,2.07]$ \\
\hline
\end{tabular}

Analysis 2.1. Comparison 2 Trials in low- and middleincome countries, Outcome 1 Death prior to hospital discharge.

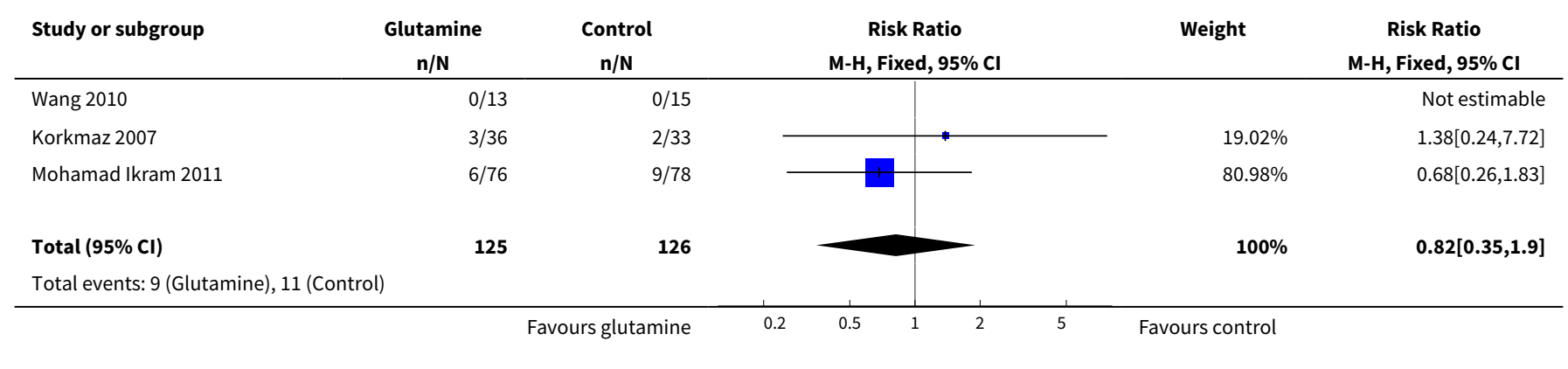




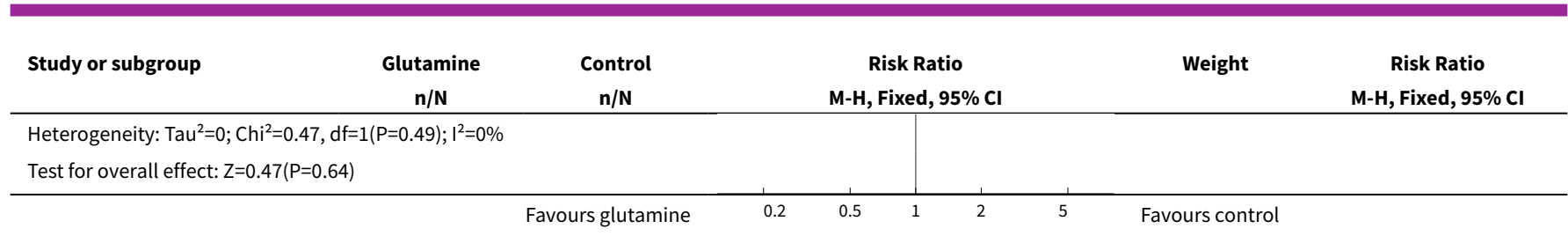

Analysis 2.2. Comparison 2 Trials in low- and middle-income countries, Outcome 2 Invasive infection.

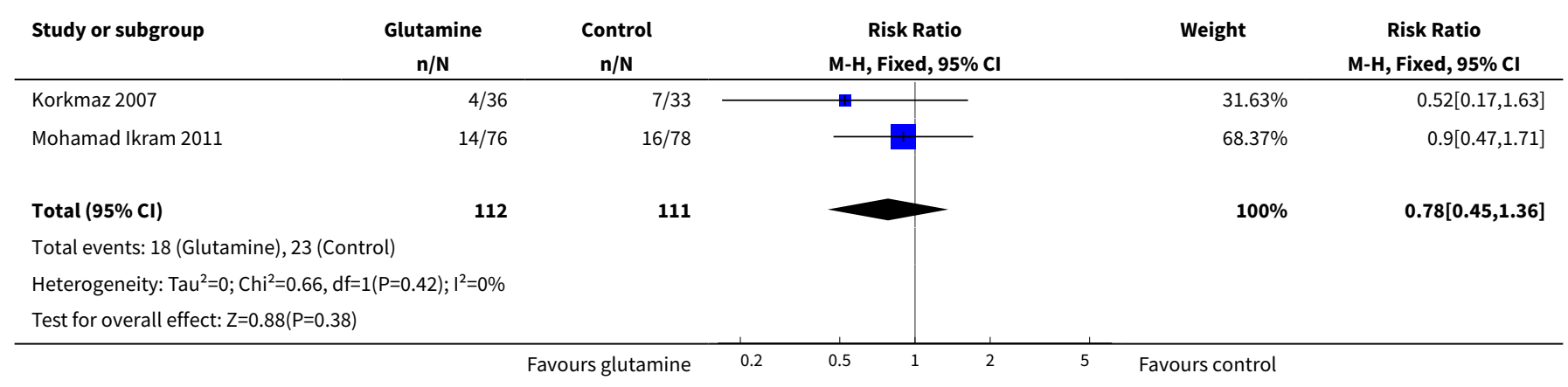

Analysis 2.3. Comparison 2 Trials in low- and middle-income countries, Outcome 3 Necrotising enterocolitis.

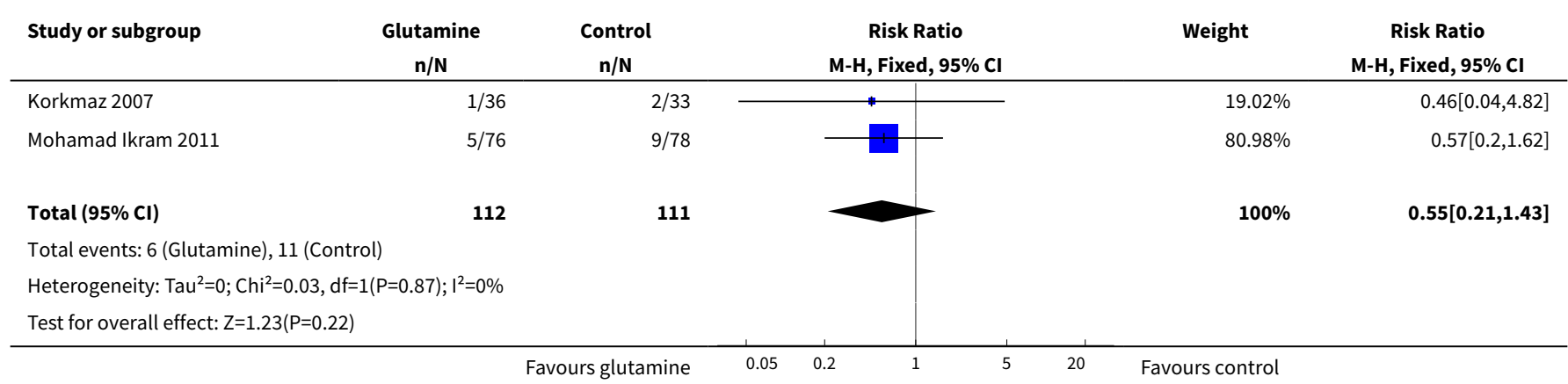

Analysis 2.4. Comparison 2 Trials in low- and middle-income countries, Outcome 4 Rate of weight gain (g/day).

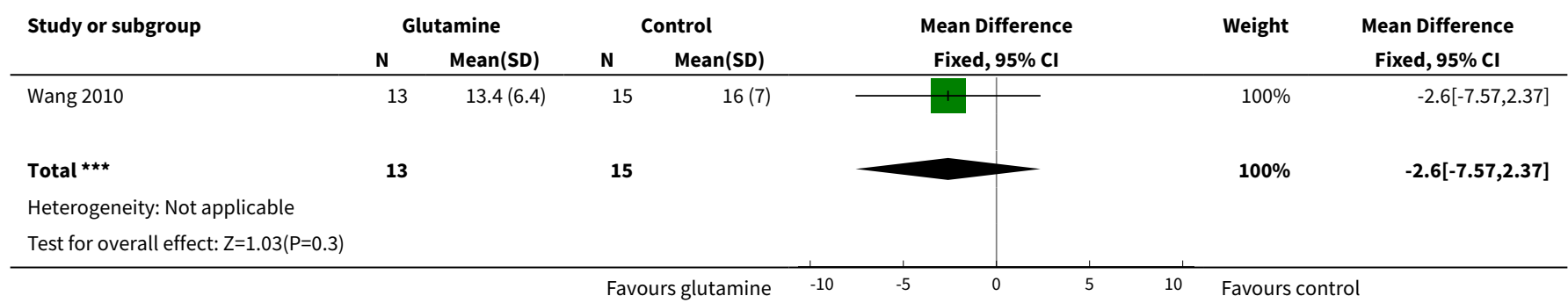


Analysis 2.5. Comparison 2 Trials in low- and middle-income countries, Outcome 5 Time to full enteral nutrition (days).

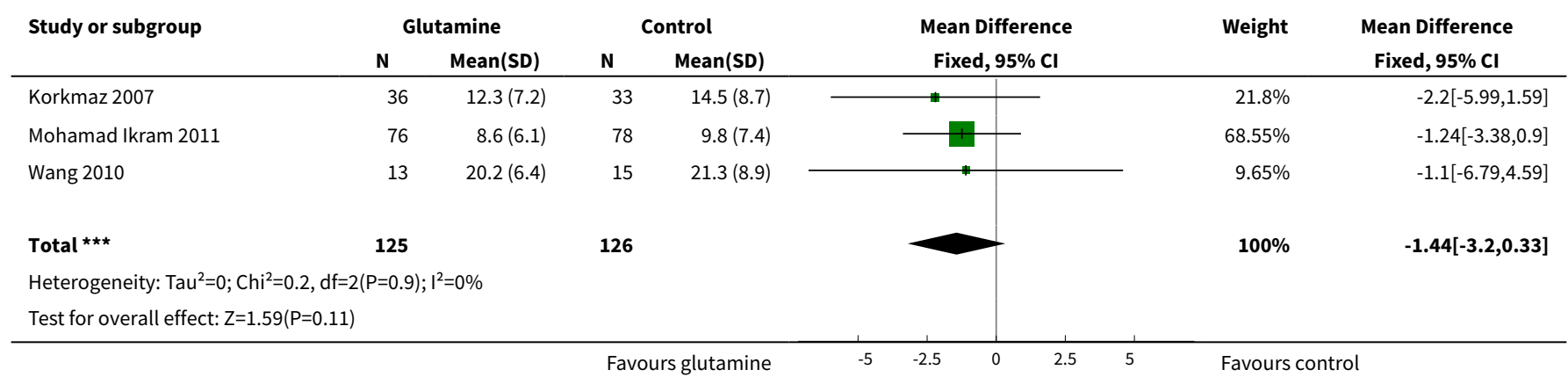

Analysis 2.6. Comparison 2 Trials in low- and middle-income countries, Outcome 6 Duration of hospital stay (days).

\begin{tabular}{|c|c|c|c|c|c|c|c|}
\hline \multirow[t]{2}{*}{ Study or subgroup } & \multicolumn{2}{|c|}{ Glutamine } & \multicolumn{2}{|c|}{ Control } & \multirow{2}{*}{$\begin{array}{c}\text { Mean Difference } \\
\text { Fixed, } 95 \% \mathrm{Cl}\end{array}$} & \multirow[t]{2}{*}{ Weight } & \multirow{2}{*}{$\begin{array}{c}\text { Mean Difference } \\
\text { Fixed, } 95 \% \mathrm{Cl}\end{array}$} \\
\hline & $\mathbf{N}$ & Mean(SD) & $\mathbf{N}$ & Mean(SD) & & & \\
\hline Korkmaz 2007 & 36 & $28.9(23.9)$ & 33 & $30.3(21.1)$ & & $13.65 \%$ & $-1.4[-12.02,9.22]$ \\
\hline Mohamad Ikram 2011 & 70 & $13.9(12.5)$ & 69 & $16.4(15.8)$ & \begin{tabular}{l|l}
1 & \\
1
\end{tabular} & $68.69 \%$ & $-2.52[-7.25,2.21]$ \\
\hline Wang 2010 & 13 & $48.7(11.4)$ & 15 & $48.3(13.8)$ & & $17.66 \%$ & $0.4[-8.94,9.74]$ \\
\hline 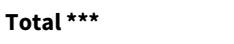 & 119 & & 117 & & & $100 \%$ & $-1.85[-5.77,2.07]$ \\
\hline Test for overall effect: $z$ & & & & & & & \\
\hline
\end{tabular}

\section{APPENDICES}

\section{Appendix 1. Electronic search strategy}

Database searches

\section{Cochrane Central Register of Controlled Trials (CENTRAL)}

Wiley http://onlinelibrary.wiley.com/

\#1 MeSH descriptor: [Infant, Newborn] explode all trees

\#2 MeSH descriptor: [Premature Birth] this term only

\#3 (neonat* or neo next nat $\left.{ }^{\star}\right): t i, a b, k w$

\#4 (newborn* or new next born* or newly next born*):ti,ab,kw

\#5 (preterm or preterms or pre next term or pre next terms):ti,ab,kw

\#6 (preemie* ${ }^{*}$ or premie or premies):ti,ab,kw

\#7 (prematur* near/3 (birth* or born or deliver $\left.\left.{ }^{\star}\right)\right): t i, a b, k w$

\#8 (low near/3 (birthweight* or birth next weight*)):ti,ab,kw

\#9 (lbw or vlbw or elbw):ti,ab,kw 
\#10 infan*:ti,ab,kw

\#11 (baby or babies):ti,ab,kw

\#12 MeSH descriptor: [Enterocolitis, Necrotizing] this term only

\#13 enterocolitis:ti,ab,kw

\#14 NEC:ti,ab,kw

$\# 15 \# 1$ or \#2 or \#3 or \#4 or \#5 or \#6 or \#7 or \#8 or \#9 or \#10 or \#11 or \#12 or \#13 or \#14

\#16 MeSH descriptor: [Glutamine] this term only

\#17 glutam*:ti,ab,kw

\#18 levoglutam*:ti,ab,kw

\#19 \#16 or \#17 or \#18

\#20 \#15 and \#19

\#21 \#15 and \#19 in Trials

\#22 \#15 and \#19 Publication Year from 2007 to 2015, in Trials

\section{Key}

MeSH descriptor $=$ indexing term (MeSH heading)

* $=$ truncation

:ti,ab,kw = terms in either title or abstract or keyword fields

near $/ 3=$ terms within three words of each other (any order)

next $=$ terms are next to each other

\section{EMBASE}

OvidSP http://ovidsp.ovid.com/

A search strategy developed by Lefebvre 2008 to identify randomised trials in EMBASE was used to limit retrieval to clinical trials (lines 22-36).

1 exp infant/

2 prematurity/

3 premature labor/

4 exp low birth weight/

5 (neonat\$ or neo nat\$).ti,ab.

6 (newborn\$ or new born\$ or newly born\$).ti,ab.

7 (preterm or preterms or pre term or pre terms).ti,ab.

8 (preemie\$ or premie or premies).ti,ab.

9 (prematur\$ adj3 (birth\$ or born or deliver\$)).ti,ab.

10 (low adj3 (birthweight\$ or birth weight\$)).ti,ab.

11 (lbw or vlbw or elbw).ti,ab.

12 infan\$.ti,ab. 
13 (baby or babies).ti,ab.

14 necrotizing enterocolitis/

15 enterocolitis.ti,ab.

16 NEC.ti,ab.

17 or/1-16

18 glutamine/

19 glutam\$.ti,ab.

20 levoglutam\$.ti,ab.

2118 or 19 or 20

22 random $\$$.ti,ab.

23 factorial\$.ti,ab.

24 crossover\$.ti,ab.

25 cross-over\$.ti,ab.

26 placebo\$.ti,ab.

27 (doubl\$ adj blind\$).ti,ab.

28 (singl\$ adj blind\$).ti,ab.

29 assign\$.ti,ab.

30 allocat\$.ti,ab.

31 volunteer\$.ti,ab.

32 Crossover Procedure/

33 double blind procedure/

34 Randomized Controlled Trial/

35 single blind procedure/

36 or/22-35

3717 and 21 and 36

38 animal/

39 exp animal experiment/

40 Nonhuman/

41 (rat or rats or mouse or mice or hamster or hamsters or animal or animals or dog or dogs or cat or cats or bovine or sheep).ti,ab,sh.

4238 or 39 or 40 or 41

43 exp human/

44 human experiment/

4543 or 44

$4642 \operatorname{not}(42$ and 45$)$

4737 not 46

Glutamine supplementation to prevent morbidity and mortality in preterm infants (Review)

Copyright $\odot 2016$ The Cochrane Collaboration. Published by John Wiley \& Sons, Ltd. 
48 limit 47 to em

Key:

/ = indexing term (EMTREE heading)

$\$=$ truncation

.ti,ab. = terms in either title or abstract fields

adj3 = terms within three words of each other (any order)

.sh.= subject heading field

.em. = entry date - date added to database

\section{Maternity and Infant Care}

OvidSP http://ovidsp.ovid.com/

1 Infant.de.

2 Infant - newborn.de.

3 Infant - premature.de.

4 infant - very premature.de.

5 Infant - low birth weight.de.

6 Infant - very low birth weight.de.

7 Premature birth.de.

8 Infant - small for gestational age.de.

9 (neonat\$ or neo nat\$).ti,ab.

10 (newborn\$ or new born\$ or newly born\$).ti,ab.

11 (preterm or preterms or pre term or pre terms).ti,ab.

12 (preemie\$ or premie or premies).ti,ab.

13 (prematur\$ adj3 (birth\$ or born or deliver\$)).ti,ab.

14 (low adj3 (birthweight\$ or birth weight\$)).ti,ab.

15 (lbw or vlbw or elbw).ti,ab.

16 infan\$.ti,ab.

17 (baby or babies).ti,ab.

18 Enterocolitis.de.

19 enterocolitis.ti,ab.

20 NEC.ti,ab.

21 or $/ 1-20$

22 Glutamine.de.

23 glutam\$.ti,ab.

24 levoglutam\$.ti,ab.

2522 or 23 or 24 
2621 and 25

27 limit 26 to yr="2007 -Current"

Key

.de. $=$ indexing term

$\$=$ truncation

.ti,ab. = terms in either title or abstract fields

$\operatorname{adj} 3=$ terms within three words of each other (any order)

$\mathrm{yr}=$ year published

\section{MEDLINE}

OvidSP http://ovidsp.ovid.com/

The Cochrane highly sensitive search strategy for identifying randomized trials in MEDLINE (sensitivity-maximizing version) was used to limit retrieval to clinical trials (lines 21-31) (Lefebvre 2011).

1 exp Infant, Newborn/

2 Premature Birth/

3 (neonat\$ or neo nat\$).ti,ab.

4 (newborn\$ or new born\$ or newly born\$).ti,ab.

5 (preterm or preterms or pre term or pre terms).ti,ab.

6 (preemie\$ or premie or premies).ti,ab.

7 (prematur\$ adj3 (birth\$ or born or deliver\$)).ti,ab.

8 (low adj3 (birthweight\$ or birth weight\$)).ti,ab.

9 (lbw or vlbw or elbw).ti,ab.

10 infan\$.ti,ab.

11 (baby or babies).ti,ab.

12 Enterocolitis, Necrotizing/

13 enterocolitis.ti,ab.

14 NEC.ti,ab.

15 or/1-14

16 Glutamine/

17 glutam\$.ti,ab.

18 levoglutam\$.ti,ab.

1916 or 17 or 18

2015 and 19

21 randomized controlled trial.pt.

22 controlled clinical trial.pt.

23 randomized.ab. 
24 placebo.ab.

25 drug therapy.fs.

26 randomly.ab.

27 trial.ab.

28 groups.ab.

29 or $/ 21-28$

30 exp animals/ not humans.sh.

$3129 \operatorname{not} 30$

3215 and 19 and 31

33 limit 32 to ed=20111101-20140911

\section{Key}

/ = indexing term (MeSH heading)

exp = exploded MeSH heading

$\$=$ truncation

.ti,ab. $=$ terms in either title or abstract fields

adj3 = terms within three words of each other (any order)

.pt. = publication type

.fs. $=$ floating subheading

.sh.= subject heading

.ed. = entry date - date added to the database

\section{MEDLINE In-Process \& Other Non-Indexed Citations}

OvidSP http://ovidsp.ovid.com/

1 exp Infant, Newborn/

2 Premature Birth/

3 (neonat\$ or neo nat\$).ti,ab.

4 (newborn\$ or new born\$ or newly born\$).ti,ab.

5 (preterm or preterms or pre term or pre terms).ti,ab.

6 (preemie\$ or premie or premies).ti,ab.

7 (prematur\$ adj3 (birth\$ or born or deliver\$)).ti,ab.

8 (low adj3 (birthweight\$ or birth weight\$)).ti,ab.

9 (lbw or vlbw or elbw).ti,ab.

10 infan\$.ti,ab.

11 (baby or babies).ti,ab.

12 Enterocolitis, Necrotizing/

13 enterocolitis.ti,ab.

Glutamine supplementation to prevent morbidity and mortality in preterm infants (Review) 
14 NEC.ti,ab.

15 or/1-14

16 Glutamine/

17 glutam\$.ti,ab.

18 levoglutam\$.ti,ab.

1916 or 17 or 18

2015 and 19

21 limit 20 to $e d=20111101-20140918$

\section{Key}

/ = indexing term (MeSH heading)

exp $=$ exploded MeSH heading

$\$=$ truncation

.ti,ab. = terms in either title or abstract fields

adj3 = terms within three words of each other (any order)

ed = entry date - date added to the database

\section{PubMed}

http://www.ncbi.nlm.nih.gov/pubmed/

The Cochrane highly sensitive search strategy for identifying randomized trials in PubMed (sensitivity-maximizing version) was used to limit retrieval to clinical trials (Lefebvre 2011).

Search $\left(\left(()\left(()\left(()\left(()\left(()\left(()\left((" I n f a n t\right.\right.\right.\right.\right.\right.\right.\right.$,$) Newborn"[Mesh])) OR ("Premature Birth"[Mesh])) OR (((neonat*[Title/Abstract]) OR neo nat* { }^{\star}$ Title/ Abstract]) OR neo-nat*[Title/Abstract])) OR (((((newborn*[Title/Abstract]) OR new born*[Title/Abstract]) OR new-born*[Title/Abstract]) OR newly born*[Title/Abstract]) OR newly-born*[Title/Abstract])) OR (((((preterm[Title/Abstract]) OR preterms[Title/Abstract]) OR pre term[Title/Abstract]) OR pre-term[Title/Abstract]) OR pre terms[Title/Abstract]) OR pre-terms[Title/Abstract])) OR (((preemie*[Title/ Abstract]) OR premie[Title/Abstract]) OR premies[Title/Abstract])) OR ((prematur [Title/Abstract]) AND birth[Title/Abstract])) OR ((prematur*[Title/Abstract]) AND born[Title/Abstract])) OR ((prematur*[Title/Abstract]) AND deliver*[Title/Abstract])) OR ((low[Title/ Abstract]) AND birthweight*[Title/Abstract])) OR ((low[Title/Abstract]) AND birth weight*[Title/Abstract])) OR ((low[Title/Abstract]) AND birth-weight*[Title/Abstract])) OR (((lbw[Title/Abstract]) OR vlbw[Title/Abstract]) OR elbw[Title/Abstract])) OR (infan*[Title/ Abstract])) OR ((baby[Title/Abstract]) OR babies[Title/Abstract])) OR ("Enterocolitis, Necrotizing"[Mesh:noexp]) OR (enterocolitis[Title/ Abstract]) OR (NEC[Title/Abstract]))) AND (((levoglutam^[Title/Abstract]) OR glutam^[Title/Abstract]) OR "Glutamine"[Mesh:noexp]))) AND $((()((()(($ randomized controlled trial[Publication Type])) OR (controlled clinical trial[Publication Type])) OR (randomized[Title/ Abstract])) OR (placebo[Title/Abstract])) OR (drug therapy[MeSH Subheading])) OR (randomly[Title/Abstract])) OR (trial[Title/Abstract])) OR (groups[Title/Abstract]))) NOT (animals[mh] NOT humans[mh])))) AND ("2011/11/01"[Date - Entrez] : "3000"[Date - Entrez])

\section{Key}

[Mesh] $=$ exploded Medical Subject heading $(\mathrm{MeSH})$

$[\mathrm{mh}]=$ exploded $\mathrm{MeSH}$

[Mesh:noexp] $=$ MeSH not exploded

* $=$ truncation

[Title/Abstract] $=$ terms in either title or abstract fields

[Date - Entrez $]=$ entry date - date added to the database

\section{Trial register searches}




\section{Clinical Trials.gov}

http://clinicaltrials.gov/

Glutamine AND (infant OR infants OR newborn OR newborns OR premature OR prematurity OR neonate OR neonates OR neonatal OR preterm OR preterms OR preemie OR preemies OR premie OR premies OR birthweight OR baby OR babies) | received on or after $11 / 01 / 2011$ | updated on or after $11 / 01 / 2011$

1 study found for: Glutamine AND (NEC OR enterocolitis) | received on or after 11/01/2011 | updated on or after 11/01/2011

12 studies found for: "Glutamine" | Child | received on or after 11/01/2011 | updated on or after 11/01/2011

metaRegister of Controlled Trials (mRCT)

http://www.controlled-trials.com/mrct/searchform

(Glutamine AND (infant OR infants OR newborn OR newborns OR premature OR prematurity OR neonate OR neonates or neonatal OR preterm OR preterms OR preemie OR preemies OR premie OR premies OR birthweight OR baby OR babies OR enterocolitis or NEC))

\section{WHO International Clinical Trials Registry Platform}

http://apps.who.int/trialsearch/AdvSearch.aspx

1. glutam* in title, clinical trials in children

2. glutam ${ }^{\star}$ in intervention field, clinical trials in children

\section{FEE D B A C K}

\section{Hans Van Rostenberghe Feedback and Review Author Response, 11 September 2007}

\section{Summary}

Glutamine has been shown to be a very useful additive to parenteral nutrition in adults. For neonates, it may be useful to consider the potential differences between developed and developing nations. Differences in nutritional status of the mothers may result in less available glutamine for the neonate. Furthermore infection rates tend to be a lot higher in settings of developing nations. Large trials in a developing nation may be still very useful to perform.

\section{Reply}

Thank you for highlighting that the findings of studies undertaken in high-income countries may not be wholly applicable to infants in low-and middle-income countries. We have pre-specified subgroup analyses of studies undertaken in low-and middle-income countries in the 2011 update of this review.

\section{Contributors}

Thirimon Moe Byrne, Jennifer VE Wagner, William McGuire.

\section{WHAT'S NEW}

\begin{tabular}{lll}
\hline Date & Event & Description \\
\hline 18 April 2016 & Amended & Minor edit \\
\hline J January 2016 & $\begin{array}{l}\text { New citation required but conclusions } \\
\text { have not changed }\end{array}$ & $\begin{array}{l}\text { Inclusion of a new trial and new follow-up data did not change } \\
\text { the conclusion. }\end{array}$ \\
\hline 18 December 2015 & New search has been performed & $\begin{array}{l}\text { This updates the review "Glutamine supplementation to pre- } \\
\text { vent morbidity and mortality in preterm infants" published in the } \\
\text { Cochrane Database of Systematic Reviews (Moe-Byrne 2012). }\end{array}$ \\
& $\begin{array}{l}\text { Updated search identified one new trial and one publication of } \\
\text { follow-up data for inclusion in this review. }\end{array}$
\end{tabular}




\section{HISTORY}

Protocol first published: Issue 2, 1999

Review first published: Issue 2, 1999

\begin{tabular}{lll}
\hline Date & Event & Description \\
\hline 30 November 2011 & $\begin{array}{l}\text { New citation required and conclusions } \\
\text { have changed }\end{array}$ & $\begin{array}{l}\text { Further evaluation of routine parenteral glutamine supplemen- } \\
\text { tation in preterm infants is unlikely to be considered a research } \\
\text { priority, but the inclusion of new trial data in this update pro- } \\
\text { vides some support for further trials of enteral glutamine supple- } \\
\text { mentation to be undertaken }\end{array}$ \\
& New authorship. \\
\hline
\end{tabular}

30 November $2011 \quad$ New search has been performed

This updates the review "Glutamine supplementation to prevent morbidity and mortality in preterm infants" published in the Cochrane Database of Systematic Reviews (Tubman 2008).

Updated search identified four new trials for inclusion in this review.

\begin{tabular}{lll}
\hline 30 November 2011 & Feedback has been incorporated & $\begin{array}{l}\text { Feedback on 2008 version of review by Hans Von Rostenberghe } \\
\text { (Feedback 1) incorporated by adding an additional subgroup } \\
\text { analysis. }\end{array}$ \\
\hline 8 May 2008 & Amended & Converted to new review format. \\
\hline 8 May 2008 & Feedback has been incorporated & Feedback incorporated \\
\hline New search has been performed & $\begin{array}{l}\text { This updates the existing review of "Glutamine supplementation } \\
\text { to prevent morbidity and mortality in preterm infants" published } \\
\text { in The Cochrane Library, Issue 1, 2005 (Tubman 2005). }\end{array}$ \\
& $\begin{array}{l}\text { One new trial was identified for this update (Bober-Olesinska } \\
\text { 2005). Inclusion of data from this trial did not change the main } \\
\text { findings or conclusions of this review. }\end{array}$ \\
\hline
\end{tabular}

\section{CONTRIBUTIONS OF AUTHORS}

JVEW, WM and TMB searched and screened the studies for inclusion, assessed the methodological quality of the trials and extracted and entered the relevant information and data from each included study independently. WM and JVEW completed the final review.

\section{DECLARATIONS OF INTEREST}

None.

\section{SOURCES OF SUPPORT}

\section{Internal sources}

- Centre for Reviews and Dissemination, University of York, UK. 


\section{External sources}

- NIHR, UK.

This report is independent research funded by a UK National Institute for Health Research Grant (NIHR) Cochrane Programme Grant (13/89/12). The views expressed in this publication are those of the authors and not necessarily those of the National Health Service, the NIHR, or the UK Department of Health.

- Eunice Kennedy Shriver National Institute of Child Health and Human Development, National Institutes of Health, Department of Health and Human Services, USA.

Editorial support of the Cochrane Neonatal Review Group has been funded with Federal funds from the Eunice Kennedy Shriver National Institute of Child Health and Human Development, National Institutes of Health, Department of Health and Human Services, USA, under Contract No. HHSN275201100016C

\section{DIFFERENCES BETWEEN PROTOCOL AND REVIEW}

None.

\section{N DEX TERMS}

\section{Medical Subject Headings (MeSH)}

*Dietary Supplements; *Infant Mortality; *Infant Nutritional Physiological Phenomena; *Infant, Premature; Glutamine [ ${ }^{\star}$ administration \& dosage]; Infant, Very Low Birth Weight; Randomized Controlled Trials as Topic

\section{MeSH check words}

Humans; Infant; Infant, Newborn 